\title{
O pensamento epistemológico-sociológico francês de Pierre BoURdIEU: POSSIBILIDADE DE SUA APLICAÇÃO NA INTEGRAÇÃo INTERNACIONAL ${ }^{*}$
}

\section{William Smith Kaku*}

\section{Introdução}

Entre o que o ser humano é ou que poderia ser e para onde ele irá, há uma questão mais fundamental que hoje se impõe, qual seja, o que ele tem feito e como tem feito as coisas para si mesmo? Tal pergunta, se não responde às especulativas questões que movimentam o intelecto humano há milênios - "quem somos ou o que poderíamos ser e para onde vamos?" - e que deu origem ao movimento de interpretação/decifração racional do mundo e da vida, entretanto, o coloca defronte de/para si mesmo, e lhe faz enxergar suas práticas, venturas e desventuras, alcançável pela ciência.

Se assim o ser humano passa a se desvelar, é para que sua trajetória históricocultural - pelo menos esse concreto que assinala toda sua existência - seja mais clara para sua própria compreensão e, quem sabe, em estágio superior ao que intelectualmente e culturalmente tem podido ser, se insira melhor na contínua construção de sua civilização e possa continuar pensando quem é ou poderia ser e para onde ele caminha, com maior consciência do que, e como tem feito as coisas em seu universo individual, social e natural.

Para pensar o que - e como - tem feito e agido no mundo social, e refletir sua aplicação a diversos campos do conhecimento humano, em especial no âmbito da integração internacional - objeto deste trabalho -, torna-se necessário buscar referencial teórico que permita, em análise crítica, debruçar-se sobre as práticas sociais cotidianas - seja qual for o espaço social referenciado-e, com o rigor do pensamento científico, construir

\footnotetext{
O presente trabalho é parte da tese doutoral do autor, intitulada "Habitus (Ethos e Práxis) na Civilização Latino-Americana uma Compreensão da Formação Social, Cultural e Ideológica da América Latina e sua Influência nos Processos de Integração Internacional Regional e Sub-Regional, com Enfoque no Mercosul", trabalho este em parte financiado pelo CNPq. Este artigo é dedicado à Profa. Dr. Cláudia Lima Marques, mui digna Coordenadora do Departamento de Direito Público e Filosofia do Direito (DIR 3) da Faculdade de Direito da Universidade Federal do Rio Grande do Sul (UFRGS) (http:// wrww.ufrgs.br).

** Doutor em Direito pelo Curso de Pós-Graduação em Direito da Universidade Federal de Santa Catarina (CPGD-UGFSC) (http://www.ufsc.br). Professor Substituto do Departamento de Direito Público e Filosofia do Direito (DIR 3) da Faculdade de Direito da Universidade Federal do Rio Grande do Sul (UFRGS), Ex-Professor Substituto do Curso de Direito, Centro de Ciências Jurídicas da Universidade Federal de Santa Catatina (CCJ-UFSC), professor de graduação em Direito e graduação em Relações intemcionais, professor de pós-graduação em Direito, educador e pesquisador em Direito e Relações Intemacionais. E-mails.smithkaku@terra.com.bresmithkaku@hotmail.com.
} 
as verdades que, justamente por serem cotidianamente reiteradas, passam despercebidas, mas que estão presentes fortemente nas causas e nos resultados das ações e decisões que são tomadas em diferentes âmbitos sociais, especialmente em uma esfera de abrangência social cujas ações e comportamentos ultrapassam as fronteiras nacionais, no caso específico, uma integração internacional regional.

Observe-se aqui que um processo de integração internacional é gerido por pessoas concretas que estão em constante inter-relacionamento social no exercício de suas elevadas atribuições públicas. São diferentes pessoas pertencentes e diferentes setores sócio-econômico-culturais, que foram construídas simbolicamente e também, ao mesmo tempo, constróem concretamente a realidade simbólica do mundo social na resultante do conjunto de forças das inter-relações sociais que cotidianamente vivem.

O objetivo desde trabalho é revelar a força epistemológica do pensamento de Pierre Bourdieu, dentro da tradição inovadora cultural francesa - por sua vez, dentro da tradição reflexiva/racionalizadora inovadora européia -, e a possibilidade de sua aplicação para interpretação dos avanços e retrocessos de um processo de integração regional, em busca de explicações mais concretas e desveladoras sobre as tomadas de decisões - ou a ausência delas - para a (in)evolução de uma integração econômica regional.

\section{Uma introdução ao pensamento de Pierre Bourdieu}

Pierre Bourdieu, sociólogo francês, com formação em filosofia e pesquisas em etnologia, estabeleceu ou desenvolveu, através de suas pesquisas e reflexões, uma filosofia da ciência denominada relacional, uma vez que dá primazia às relações que se inserem os objetos de pesquisa, uma vez que são essas relações que dão o sentido e significado de diversas ações e comportamentos humanos num determinado contexto histórico-cultural, uma vez que o ser humano produz concretamente sua vida social - vale dizer, tudo que ele faz ou deixa de fazer - nas e pelas inter-relações travadas, com os sentidos específico- históricos - que lhes são conferidos. ${ }^{1}$

Para o autor francês, a ciência social estabelece objetos ou realidades substanciais como individuo, grupos, entre muitos outros mais, mas não se atém fortemente às relações objetivas intangiveis que essas realidades estabelecem com o meio onde se inserem e que somente podem ser verificáveis - tais relações - através de um processo difícil de construção e validação por meio do trabalho científico. ${ }^{2}$

1 BOURDIEU, Pierre. Razões práticas: sobre a teoria da ação. São Paulo; Papirus, 1997, p.9. As pesquisas de Pierre Bourdieu estenderam-se, ao longo de sua carreira com pesquisador, por muitas disciplinas como etnologia, sociologia, filosofia, sóciolingüística, economia, história. In: BOURDIEU, Pierre. Los uso sociales de la ciencia. Buenos aires; Nueva Vision, 2003, p. 63.

2 BOURDIEU, Razões..., p. 9. 
Também concebeu ou desenvolveu uma filosofia da ação, que denominou como disposicional, por desvelar as potencialidades inscritas nos corpos dos agentes ${ }^{3}$ e nas estruturas das situações onde eles atuam relacionalmente, ${ }^{4}$ através do que ele denomina por babitus, campo e capital. ${ }^{5}$ Desta forma, ele iniciou opor-se, a seu modo, às explicações consagradas para ações ou representações humanas, fundadas de forma inexorável em uma razão explicitamente dada por um indivíduo autônomo, plenamente consciente de suas motivações. ${ }^{6}$

Considerando que ele trabalha com o simbólico - marcante e condicionador edificado através da comunicação humana, e que o estruturalismo ${ }^{7}$, como teoria do conhecimento - epistemologia - ou método de pesquisa das ciências humanas e sociais nasceu - em seu sentido moderno - dos lingüistas, seu enquadramento dentro da corrente estruturalista foi devidamente anotado, ${ }^{8}$ entretanto, como o próprio sociólogo francês terá oportunidade de explicar, ele não recusa o enquadramento, mas se afasta de certa corrente estruturalista que insere os agentes a simples epifenômenos da uma estrutura, ao mesmo tempo em que, ao recusar essa redução, Bourdieu não os eleva a sujeitos absolutamente livres e autônomos em. suas manifestações e ações sociais.?

3 Bourdieu verificou que tais disposições inscritas nos corpos dos agentes implicam que os mesmos já estão previamente predispostos a determinadas ações e reações, condicionantes de seu modo de ser. Sobre isso vide, entre outros: BOURDIEU, Pierre. La distinción: criterio y bases sociales del gusto. 2. ed. Madtid: Taurus, $2000600 \mathrm{p}$. (obra recentemente traduzida no Brasil pela Editora Zouk) e BOURDIEU, Pierre. Razões práticas: sobre a teoria da ação. São Paulo; Papirus, 1997.

4 Bourdieu verificou que tais estruturas de situações também atuam para as respostas possíveis dos agentes nela inseridos, conforme determinadas situações a que esses agentes acabam se submetendo no seu cotidiano. São como que "programações" - probabilidades, é importante ressaltar - de respostas para certas situações. Sobre isso vide, entre outros: BOURDIEU, Pierre. La distinción: criterio y bases sociales del gusto. 2. ed. Madrid: Taurus, 2000.600 p. (obra recentemente traduzida no Brasil pela Editora Zouk) e BOURDIEU, Pierre. Razões práticas: sobre a teoria da ação. São Paulo; Papirus, 1997

5 BOURDIEU, Fazões..., p. 10

6 BOURDIEU, Razões..., p. 10.

7 A origern do conceito teve um sentido arquitetural, ou seja, a maneira de se construir um edificio; postexiormente assume o sentido de descrição da forma "como as partes integrantes de um ser concreto organizam-se numa totalidade". Foi no século XIX que o estruturalismo aportou no campo das ciências humanas, designando "um fenômeno duradouro que combina de maneira complexa as várias partes de um conjunto numa acepção mais abstrata". O estruturalismo nasce para sua significação como método modemo de busca de verdades científicas, através da linguística, pela Escola de Praga ou Círculo Linguístico de Praga In: DOSSE, François. Histónia do estruturalismo: o campo de signo, 1945/1966. São Paulo: Ensaio; Campina: Editota da Unicamp, 1993, vol. 1, p. 15; OUTHWAITE, William; BOTTOMORE, Tom; et alii. Dicionário do pensamento social do século XX. Rio de Janeiro: Jorge Zahar, 1996, p. 275. Este método de indagação, que provocou uma verdadeira revolução em todas as ciências humanas no séc. XX, a ponto de considerarem que aqui haviam conquistado seu batismo científico, tomou-se influente especialmente nos anos 60 e 70 . Ele procurou enfatizar "a importância fundamental de identificar e analisar as 'estruturas profundas" que estão na base e que geram os fenômenos observáveis". Nas ciências sociais ele se opôs ao humanismo, historicismo e empirismo. Foi anti-humanista porque excluiu de suas análises ações conscientes e deliberadas de indivíduos e gnupos sociais por estarem inseridos numa causalidade estrutural; foi anti-historicista porque deu preferência "pelas investigações sincrônicas, em vez das diacrônicas, com o objetivo de descobrir as características estruturais universais da sociedade humana $\mathrm{e}(\ldots)$ relacionar (...) às estruturas da mente humana"; anti-empirista por insistir numa eficácia causal de uma estrutura profunda subjacente à aparência superficial e imediata dos eventos. Bastante criticada, no final dos anos 70 diminuiu sua influência enos anos 80 viu ascender o pós-estruturalismo ou pós-modemidade. Entretanto, verifica-se que perdida sua fecundidade de outrora, teóricos sociais, de forma menos extremada, tem trabalhado metodologicamente a respeito da relação entre estrutura e mediação humana, ou estrutura e mudança histórica. In: OUTHWAITE; BOTTOMORE; et alii, idem, p. 275-6; DOSSE, idem, p. 16

8 François Dosse explica que o estruturalismo, no campo das ciências sociais, estaria dividido historicamente em a) estruturalismo científico, que envolveria antropologia, semiótica e psicanálise; b) estruturalismo semiológico, mais cambiante, flexível quanto a uma lei estrutural govemante; e c) um estruturalismo historicizado ou epistêmico, onde, nessa última corrente estaria localizado Pierre Bourdieu. In: DOSSE, idem, p. 16

9 BOURDIEU, Razões..., p. 10. 
Ao proceder desta forma, ele rompe com noções consagradas que circulam no discurso acadêmico de forma já naturalizada - sujeito, motivação, ator, papel, etc. -, e sobre elas lança uma mirada que até então nada semelhante havia sido feito, para estabelecer um outro grau de discussão mais crítica, bem como rompe com os diversos pares teóricos - consagrados de oposições que os acompanham e que constituem a própria construção do imaginário social - indivíduo/sociedade, individual/coletivo, consciente/inconsciente, objetivo/ subjetivo, etc. ${ }^{10}$

Suas descobertas propõem modos controlados e constantes de agir e de pensar e que constituem um método para a busca da representação realista da ação humana, que para o pensador é condição primeira para um conhecimento científico do mundo social em suas várias dimensões, pois a análise sociológica passa a ser um dos instrumentos poderosos para conhecimento de alguém próprio, com ser social e, desta forma, como ser singular, pois "oferece alguns dos meios mais eficazes de acesso à liberdade que o conhecimento dos determinismos sociais permite conquistar contra os determinismos". "Uma pesquisa que traga a compreensão rigorosa do mundo é parte dos instrumentos de libertação com que o ser humano - individual ou coletivamente - conta para si, e seu método trata-se de um guia para se aplicar a uma prática. ${ }^{12}$

As pesquisas de Pierre Bourdieu centraram-se em sua maioria na França. O início de sua atividade de pesquisador ocorreu no norte da África, numa das colônias da França, estudando os efeitos da mudança de uma sociedade pré-capitalista - agrário - para capitalista, o confronto entre a tradição e as imposições sociais de uma nova economia que não pode sobreviver com a velha. De qualquer modo, suas análises voltaram-se para sociedade diferenciadas por classes, definidas enquanto tais pelo próprio avanço ou evolução de uma economia capitalista, os denominados páses desenvolvidos. Assim, seus modelos de reflexão foram construídos especialmente a partir do caso da França, ${ }^{13}$ mas com intenção de validade universal para outras sociedades com as mesmas características sócio-econômicas.

Para Bourdieu, seria possivel analisar a Alemanha, o Japão, os EUA, através de seu método de pesquisa social, apenas com o porém de considerar seriamente particularidades ou singularidades que seriam mais marcantes historicamente no desenvolvimento cultural e social de cada povo, e sem cair num perigoso etnocentrismo. ${ }^{14}$ Referência direta ao uso de seu método em países em desenvolvimento, somente analisando suas pesquisas iniciais em

10 BOURDIEU, Razões.., p. 10.

11 BOURDIEU, Razões..., p. 11-2.

12 BOURDIEU, Razões..., p. 8

13 BOURDIEU, Razões..., p. 9 e 28.

14 BOURDIEU, Razões..., p. 15. "Se a 'imigração de idéias" (...) ratamente se faz sem dano, é porque ela separa as produções culturais do sistema de referências teóricas em relação às quais as ideias [sic] se definiram, consciente ou inconscientemente, quer dizer, do campo de produção balizado por nomes próprios ou por conceitos em -ismos para cuja definição elas contribuem. menos do que ele as define. Pot isso, as situações de 'imigração' impõem com uma força especial que se tome visivel o horizonte de referência o qual, nas situações correntes pode permanecer em estado implícito. Embora seja escusado dizer que repatriar este produto de exportação implica sérios tiscos gxaves de ingenuidade e de simplificação - e também grandes inconvenientes, pois fornece um instrumento de objectivação" (grifos no original). In: BOURDIEU, Pierre. O poder simbólico Rio de Janeiro: Bertrando do Brasil, 1998, p. 7 . 
etnologia na África e construindo a possibilidade de um espaço de aplicação para sociedades como as latino-americanas. ${ }^{15}$

\section{Uma breve sistematização do pensamento de Pierre Bourdieu}

Quem acompanha a produção teórica de Pierre Bourdieu, verifica que o autor e intelectual francês não sistematizou sua obra, no sentido de apresentar sua produção investigativa de forma estruturada conforme cânones seguidos pela academia - pelo menos a brasileira -, vale dizer, introdução, desenvolvimento e conclusão, com os conceitos teóricos e operacionais previamente delimitados, tema, delimitação do tema, problemas e hipóteses claramente e previamente delimitados etc., de tal forma que a leitura dos seus estudos e conclusões demandam um esforço maior do pesquisador a fim de tentar sistematizar o que o próprio autor se recusou a fazer ou não se preocupou em elaborar em vida. De fato, a compreensão do conjunto de sua obra deve passar necessariamente pelos diversos artigos que ele escreveu, livros específicos - de fôlego investigativo e reflexivo - e entrevistas que o sociólogo concedeu enquanto vivo. Essa forma peculiar de escrever foi observada por ele numa entrevista, dizendo que ele assim procedia conforme um autor que ele havia lido quando iniciava sua carreira de pesquisador social.

Pierre Bourdieu solicitou encarecidamente, à sua maneira, que não o dogmatizassem, que não lançassem seus estudos e conclusões - teorias, conceitos, abstrações sobre o social etc. - conforme era praxe nas práticas de um determinado setor da academia, que acabavam enrijecendo um dado autor e respectiva teoria utilizada, não estando aberto epistemologicamente e teoricamente para outras abordagens igualmente construtivas de saberes e conhecimentos importantes para avançar o entendimento do mundo social.

Assim, de certa forma, a sistematização que segue abaixo é uma heresia que se comete contra o pensamento de Pierre Bourdieu, haja vista que corre-se o risco de contribuir para a dogmatização de uma pensamento que, antes de tudo, solicita do pesquisador uma luta constante de si próprio para si próprio, a fum de, numa sócioauto-análise, identificar esses comportamentos ou atitudes que não permitem a ciência avançar e sempre estar alerta numa vigilância epistemológica constante contra esse tipo de ignorância erudita.

\footnotetext{
15 Toda sociedade - mesmo os exemplos históricos que foram construídas como ausente de classes - constrói seu espaço social e o espaço simbólico, conforme princípios fundamentais de diferenciação ou de distinção e erige para o mundo seu modelo como um dos casos particular dos possíveis. Na França, verificou-se que levando em conta os diferentes tipos de capital e sua distribuição no espaço social, o capital econômico $€$ o capital cultural tinham um peso fundamental na estrutura daquele, 0 que condicionou as pesquisas do sociólogo francês. No entanto, é preciso verificar em cada sociedade quais são seus princípios de diferenciação característicos para constatar verdadeiramente o que está na base das diferenças sociais; qual tipo de capital, qual princípio de diferenciação, cuja distribuição desigual govema as diferenças no espaço social. Assim, por exemplo, é possível vislumbras o capital político que pode assegurar aos seus detentores um poder simbólico e material muito grande e ser a base fundamental - ou mais importante e significativa - de todas as diferenças no espaço social, confrontados sempre pelos detentores do capital escolar. In: BOURDIEU, Razões..., p. 27-32.
} 
Entretanto, a abordagem sistemática que se pretende abaixo em nenhum momento referenda a canonização do pensamento de Pierre Bourdieu, mas contrariamente, procura aborda-lo dentro da vigilância epistemológica que requer a ciência social, revelando por que não se deve trabalhar sobre cânones científicos.

Assim, aqueles que acompanham a obra de Pierre Bourdieu, entendem que ele inovou a área das ciências sociais influenciando pesquisas sociológicas, antropológicas e inclusive históricas em todo o mundo. $\mathrm{O}$ aspecto mais marcante de sua obra está na escolha dos objetos de análise (como sociedades tribais, sistema de ensino, processos de reprodução social, critérios de classificação social, lógicas de distinção social), na mirada ou reorientação do olhar frente a esses objetos (para melhor compreensão dos fenômenos de percepção social, a força da produção simbólica e seus efeitos sociais, as relações de poder informalizadas presentes e atuantes na sociedade), na formulação de noções operatórias (habitus, poder simbólico, capital, campo, etc.), e no recurso à sociologia do conhecimento ou epistemologia sociológica (onde a posição do investigador é constantemente questionada como forma de controle do seu trabalho de produção de sentido para o mundo social).${ }^{16}$

Estudando a crise de um mundo campesinato e o choque essa sociedade rural com o espírito do capitalismo, a sua pesquisa científica inicia com observações sobre o processo de aculturação numa sociedade tribal norte-africana - os cabilas - vivendo nas margens da sociedade moderna, verificando o fato a partir (I) da organização familiar e social, (II) percepção do tempo e do espaço e (III) visão de mundo. Essa pesquisa inicial permitirá que o sociólogo francês utilize esse campo de observação para analisar a sociedade argelina como um todo e fará com que supere as divisões tradicionais do saber entre antropologia, sociologia e economia, num processo voltado para alcançar a efetiva e real compreensão - ou o que possa mais próximo disso ser considerado - de uma dada formação social. Após estudar uma sociedade tribal e um país subdesenvolvido, colônia da França, ele se dirige à ao seu país de origem, especificamente à sua terra natal, ou região de origem - Béarn -, a fim de estudá-la de acordo com seus primeiros marcos intelectuais. ${ }^{17}$

Feito isso, ele deixa de dirigir seu foco de estudos para o âmbito rural, para os espaços sociais ou formações sociais distantes dos centros urbanos; mas influenciado pelas constatações teóricas verificadas, passa para o estudo da complexidade do mundo social - espaço social ou formações sociais - urbano, enfim, para o centro da sociedade moderna, elegendo a educação e seus protagonistas, mais especificamente suas práticas relacionais, como novo alvo para continuidade de suas reflexões científicas. Numa sociedade diferenciada em classes ou grupos, de que forma ela se reproduz - de forma

\footnotetext{
16 BOURDIEU, O poder..., p.1.

17 BOURDIEU, O poder..., p. 1. Nessa época ela já verifica que a crise do mundo rural tradicional ou do campesinato não se justifica apenas pela emergência do capitalismo agrário, com suas novas praticas e racionalidade incompativeis com um mundo tradicional não fundado na racionalidade instrumental, mas também por outros mecanismos muito mais sutis presentes nessa realidade tradicional, entre outros a reprodução biológica do indivíduo e a própria reprodução desse mundo. Aqui a noção de habitus já começa por se forjat. In: BOURDIEU, Los usos..., p. 64-5.
} 
inconsciente mesmo, ou naturalizada - tendo em foco a problemática da educação - em especial seu sistema de ensino - e a origem social dos seus protagonistas (família, instituições, professores, alunos, etc.)? A resposta é que o capital cultural acumulado tem um papel fundamental no processo de seleção escolar e na reprodução das práticas culturais de uma dada formação social. Isso possibilita questionar - de uma maneira inusitada - a autonomia aparente do sistema de ensino; também a idéia de igualdade de oportunidades sociais; bem como as diferenças de capital econômico, social e cultural, como determinantes nas escolhas e opções previamente assumidas mas dissimuladas. ${ }^{18}$

Estudando a arquitetura gótica e o pensamento escolástico, verificou como um mesmo habitus acaba produzindo efeitos em manifestações as mais diversas; estudando a fotografia, o livro e a pintura, verificou como a apropriação de tais objetos culturais por diversos agentes - e sua luta pela busca de autonomia dos objetos e suas práticas correlativas - contribuíram para valorizar as práticas dos grupos sociais constituídos em torno desses bens culturais ao longo do tempo; estudando grupos específicos de especialista em produção simbólica - como profetas, padres, intelectuais -, verificou como um ato de criação está inserido num campo ou mercado específicos, ou seja, submetidos a dadas condições sociais de produção; e refletindo com um grupo de especialistas sobre o oficio de sociólogo, procurou constituir um ponto de partida - para formulação de uma teoria da prática, enfim, uma forma de estabelecer uma vigilância epistemológica do próprio agir científico de quem faz ciência social, a fim de libertá-lo do que denomina por sociologia espontânea, verdade sobre o mundo social obtida equivocadamente, que faz aceitar-se como um dado inquestionável erroneamente - fatos sociais em curso ou presentes num objeto de pesquisa. ${ }^{19}$

Quando ingressa no College de France passou a trabalhar para a constituição de uma teoria geral dos campos que permeiam uma sociedade; dedicou-se à sociologia do gosto e às distinções e classificações que se estabelecem num espaço social; denunciou a concepção estratificada - estratigráfica - da realidade social; aprofundou o estudo das instituições escolares e desvelou o conjunto de campos e poderes inerentes às universidades. ${ }^{20}$ Nesse retorno ao sistema de ensino, ele especifica melhor como se constituem os campos de produção da cultura, como as artes, ciências, etc. Verifica que existem campos de produção estreitos ou restritos, vale dizer, um campo de produção de cultura onde os produtores têm por público direto e essencial os próprios concorrentes diretos, qual sejam, os outros produtores. ${ }^{21}$

Ao estudar a especificidade do campo científico e as condições sociais do progresso da razão, Bourdieu rompe com a tradição dominante na sociologia da ciência, tradição essa que

${ }^{18}$ BOURDIEU, O poder..., p. 2. A escola não só reproduz a estrutura social, ela faz parte de um processo mais amplo em curso numa formação social, que é o da violència simbólica como pedagogia, em sentido amplo, dos valores legítimos a serem cultivados pelos seus destinatários. In: BOURDIEU, Los usos..., p. 65

19 BOURDIEU, O poder..., p. 2-3

20 BOURDIEU, O poder..., p. 3-4. Na busca da interpretação dos processos de diferenciação social Bourdieu constrói uma teoria sociológica das categorias que organizam a percepção do mundo social e contribuem com eles a realizá-lo; o estudo dos gostos, das apreciações estéticas, do consumo geral dos objetos culturais ou classificados como tais, permitem compreender melhor os mecanismos de diferenciação ou afirmação de distâncias pelos grupos sociais dominantes e dominados. BOURDIEU, Los usos..., p. 66.

21 BOURDIEU, Los usos..., p. 67. 
assevera o fato de que haveria - e bastaria analisar essa constatação evidente - a existência ou a constataçâo de uma denominada comunidade científica, com todas a suas conseqüências mais imediatas, para revelar a verdade social do campo científico, em tudo que faz/produz e deixa de fazer/produzir; ele introduz os conceitos de campo e capital científico, e revela que a lógica de um mercado pode ser aqui aplicada, mostrando que os agentes nesses campos têm nos seus principais concorrentes os seus clientes diretos. Isso lhe permite avançar e verificar a função específica da academia, o ensino superior, com seu corpo docente e suas práticas academicistas, a luta entre as disciplinas, o ranço escolástico, as crises do campo, além de relacionar o Estado e algumas específicas instituições universitárias de onde saem tradicionalmente o corpo burocrático estatal, nesse último caso, analisando de forma singular a instituição estatal. ${ }^{22}$

Ao longo de sua vida, Pierre Bourdieu concedeu inúmeras entrevistas em diversos meios de comunicação, a fim de esclarecer o conteúdo de suas obras e suas opções como pesquisador e os resultados - polêmicos - obtidos. Nos últimos anos de sua vida continuou polemizando por suas atitudes e ações políticas, que foram objeto de manifestações diversas na mídia francesa em geral e frente a seus pares, uma vez que a tradição recomenda que o intelectual fique circunscrito ao campo de sua especialidade e não se exponha em outras esferas ou campos sociais que não são seu mètier.

\subsection{Espaço social e espaço simbólico}

A pesquisa de Pierre Bourdieu se funda em que não é possível capturar a lógica mais profunda do mundo social a não ser com o pesquisador e cientista mergulhando completamente na particularidade de uma realidade empírica que é historicamente situada e datada para, a partir daí, construí-la como um caso do possível, de acordo com o que Gaston Bachelard ${ }^{23}$ especificou, ou seja, uma figura num universo de configuração possível. Como apreender estruturas e mecanismos que escapam aos olhares, e que são princípios de construção do espaço social ou mecanismos de reprodução desse espaço ${ }^{24}$

Analisando o modelo que ele construiu para realizar sua obra "A Distinção: critérios e bases sociais do gosto", 25 alerta para o fato de que tornou-se necessário fugir de uma leitura que ele denomina por "substancialista", onde considera cada prática ou consumo em si mesmas e por si mesmas, independente do universo de práticas intercambiáveis, de tal forma a conceber de forma ingênua como realidade, ao final, a correspondência entre as posições sociais - ou classes - e os seus gostos e práticas como uma relação direta e mecânica. ${ }^{26}$

\footnotetext{
22 BOURDIEU, Los usos..., p. 67-8.

23 Gaston Bachelard (1884-1962), filósofo francês que elaborou uma epistemologia histórica, onde buscou considerar as ciências no seu desenvolvimento e aquilo que se chamou por uma psicanálise do conhecimento objetivo. In. GRANDE ENCICLOPÉDIA LAROUSSE CULTURAL. São Paulo: Nova Cultural, 1998, v. 3.

24 BOURDIEU, Razões..., p. 15.

25 Obra recém traduzida no Brasil pela Editora Zouk. BOURDIEU, Pierre. La distinción: criterio y bases sociales del gusto. Madrid: Taurus, 2000.597p

26 BOURDIEU, Razões.., p. 16.
} 
Tal modo de pensar "substancialista" leva ao erro de pensar que as atividades ou preferências próprias de cada indivíduo ou cada grupo de uma dada sociedade são propriedades inscritas numa espécie de essência biológica ou cultural em cada qual, pensamento que se estabelece como senso comum e que pode chegar ao racismo, uma vez que discriminatório ele já é por si. Ora, as práticas se alternam como tempo e o movimento histórico é importante para entender, numa dada sociedade, seu comportamento e escolhas em vigor. Ademais, as propriedades de um determinado grupo ou de certos indivíduos são dadas conforme a situação histórica ou contexto impõe como oferta de bens e práticas possíveis. ${ }^{27}$

Assim, é possível constatar que posições sociais, disposições - ou habitus - e tomadas de posição dos agentes ou grupos, nas mais diversas esferas de sua vida cotidiana, estão inter-relacionados e interagindo-se interdependentemente. Alerta que a comparação que pode ser feita entre certos indivíduos ou grupos de diversas sociedades somente é possível intersistemas, uma vez que a equivalência analítica direta através de traços isolados arrisca-se a resultados equivocados tendo em vista diferenças estruturais presentes historicamente em cada sociedade. A distinção, que é tão presente no mundo social, "é de fato diferença, separação, traço distintivos, (...) propriedade relacional que só existe em relação a outras propriedades". ${ }^{2}$

Tal constatação - presença social da distinção - não é de evidência e conseqüências tão simples assim, pois essa idéia marcada de diferença, separação, está exercendo uma verdadeira fronteira invisível no espaço social, como conjunto de posições distintas e coexistentes, delimitando e definindo - até geograficamente - posições de localização de agentes ou grupos, em suas várias disposições e tomadas de posição. Esse espaço social como conjunto de disposições distintas mas coexistentes entre si, faz com que essas posições sejam definidas, numa circularidade, uma em relação às outras, umas mais próximas e outras mais distantes e por uma relação até de hierarquia posicional, sempre auto-referentes por sua exterioridade coexistencial mútua. ${ }^{29}$

No espaço social, é o capital econômico e o capital cultural - dois princípios de diferenciação - que irão ditar a distribuição dos agentes e grupos e fixar sua posição, desta forma, em se colocando num gráfico essa distribuição, verificar-se-á que os agentes e grupos tem tanto mais em comum quanto mais próximos estejam nessas dimensões econômica e cultural; ${ }^{30}$ assim, as distâncias representadas graficamente correspondem a distâncias sociais que, por sua vez, equivalem a diferenças dos agentes e grupos nas disposições e tomadas de posição. $^{31}$

Suas pesquisas revelaram que nesse gráfico de distribuição de agentes sociais dentro do espaço social, "o espaço de posições sociais se retraduz em um espaço de tomada de posição pela intermediação do espaço de disposições (ou do babitus); ou, em outros termos, ao sistema de separações diferenciais, que definem as diferentes

27 BOURDIEU, Razões.., p. 17-8

28 BOURDIEU, Razões..., p. 18. Grifos do autor.

2 BOURDIEU, Razões..., p. 18-9.

30 Para melhor entendimento, existem diferentes posições ou dimensões econômicas e culturais historicamente construídas na sociedade, onde as pessoas nela se inserem conforme condições sociais específicas de inserção

31 BOURDIEU, Razões..., p. 19-21. Na página 20 o sociólogo reproduz o gráfico correspondente ao espaço das posições sociais e espaço dos estilos de vida, extraído de sua obra "A Distinção". 
posições nos dois sistemas principais do espaço social, correspondem um sistema de separações diferenciais nas propriedades dos agentes (ou de classes construídas como agentes), isto é, em suas práticas e nos bens que possuem. A cada classe de posições corresponde uma classe de habitus (ou de gostos) produzidos pelos condicionamentos sociais associados à condição correspondente e, pela intermediação desse habitus e de suas capacidades geradoras, um conjunto sistemático de bens e de propriedades, vinculados entre si por uma afinidade de estilo". 32

\subsection{O habitus}

A noção de habitus - e sua função - nasceu exprimindo o sentido e significado de uma recusa a um conjunto de alternativas explicativas que fundamentariam certas práticas e comportamento dos agentes, presentes no mundo social, e que haviam sido adotadas pela ciência social como definitivas. Seriam as explicações que, como lugarescomuns eruditos, dominariam como princípios explicativos do proceder humano; assim, em última instância, o ser hưmano faz o que faz porque isso deriva ou de sua consciência - sujeito -, ou da sua inconsciência, ou de um finalismo, ou de um mecanicismo, e assim por diante. ${ }^{33}$

Foi através da leitura de dois textos de Erwin Panofsky, ${ }^{34}$ um deles explicando os efeitos do pensamento escolástico no terreno da arquitetura, que emergiu a noção fundamental de "habitus" e que, por sua vez, possibilitou o rompimento do sociólogo francês com um certo estruturalismo, um paradigma estruturalista que, quando abandonado, inclinava imediatamente os cientistas a se socorrerem na alternativa da filosofia do sujeito $^{35}$ ou da consciência, ${ }^{36}$ ou mesmo da economia clássica e do seu

32 BOURDIEU, Razões..., p. 21. Itálicos no original

33 BOURDIEU, O poder..., p. 60.

34 Erwin Panofsky (1892-1968), historiador de arte norte-amencano de origem alemã, que desenvolveu o método iconológico, visando a leitura da obra de arte em seu contexto de civilização e segundo seus diferentes níveis de significação. In: GRANDE ENCICLOPÉDIA LAROUSSE CULTURAL. São Paulo: Nova Cultural, 1998, v. 18

35 E expressão "sujetto" tem dois significados fundamentais: a) aquilo que se fala ou a que se atribuem qualidades ou determinações ou a que são inerentes qualidades ou determinações. Trata-se de predicados inerentes ou determinações referentes a um objeto real - significados ou denotações sobre um objeto, abrangendo até a própria alma humana -, que pode ser ou a matéria que se compõe uma coisa, ou a forma da própria coisa, ou a própria união da matéria a uma forma, b) o eu, o consciente ou a capacidade de iniciativa em geral. No sentido tradicional do termo o eu é sujeito na medida em que seus pensamentos lhe são inerentes com predicados. Num novo sentido, o eu é sujeito na medida em que determina a união entre sujeito e predicado nos juizos, na medida em que é atividade sintética ou judicante, espontaneidade cognitiva, portanto, consciência, autoconsciência e apercepção In: ABBAGNANO, Nicola. Dicionário de filosofia. São Paulo: Martins Fontes, 1998, p. 929-30.

36 Num primeiro sentido, consciência é a possibilidade que tem o ser humano de dar atenção aos próprios modos de ser e às próprias ações, bem como de exprimi-los com a linguagem; ou seja, consciência aqui significa a pessoa estar ciente dos próprios atos, estados, percepções, idéias, sentimentos, volições etc - assim se basearam as filosofias de Platão e Aristóteles -, sendo que somente com base nessa possibilidade é que foi possível erigir a noção filosófica da consciência. Portanto, em seu segundo sentido, é o significado filosófico da expressão consciência na filosofia moderna e contemporânea, que pressupondo a acepção comum, entretanto é mais complexa. Na filosofia moderna e contemporânea, consciência quer significar uma relação da alma consigo mesma, uma relação intrínseca ao ser humano "interior" ou "espiritual" onde ele pode conhecer-se de modo imediato e privilegiado e também efetuar julgamentos próprios de modo infalível e seguro; nesta noção, os aspectos morais têm conexões estreitas com o aspecto teórico, enfim, a possibilidade de conhecer-se de modo direto e infalível. In: ABBAGNANO, Nicola. Dicionário de filosofia. São Paulo: Martins Fontes, 1998, p. 185. 
homo economicus. ${ }^{37} \mathrm{O}$ uso da expressão é uma reconversão do termo hexis, feita pelos
escolásticos, noção fixada e utilizada inicialmente por Aristóteles, ${ }^{38}$ e tratou-se - como
assinalado - de uma reação contra o estruturalismo e sua filosofia da ação que reduzia um
agente social a mero suporte da estrutura; para isso, para retomar o agente a um papel ativo
ou como ele acaba por construir suas determinações, a noção de babitus permitiu enxergar as

37 O homem econômico foi um conceito criado pelos economistas da Escola Clássica, pelo qual o ser humano seria motivado exclusivamente por razões econòmicas, desta forma preocupando-se em termos imediatos em obter um máximo de lucro com um mínimo de sactifício; ele agiria racionalmente no sentido de maximizar sua riqueza e assim introduzir novos métodos produtivos para enfrentar a concorrência no mercado. Foi a Escola Histórica alemã que se contrapôs a essa corrente abstrata do comportamento do ser humano, procurando estudar os seres humanos reais, situando-os em diferentes épocas históricas e condições sociais. In: DICIONÁRIO DE ECONOMIA. Coleção os Economistas. São Paulo: Abril, 1985

3 Aristóteles (384-322 a. C.), filósofo grego, discípulo e crítico de Platão e o mais renomado entre os filósofos de seu tempo. Após a morte de seu pai Nicômaco, médico do Rei Amintas, aos 17 anos integrou-seà Academia de Platão, onde permaneceu - cerca de 20 anos - até pouco após a morte deste em 348-7 a.C. Posteriormente foi designado tutor de Alexandre o Grande. Em 335 voltou para Atenas, onde fundou uma escola - Liceu ou escola peripatética, porque ele, como mestre, costumava dar suas lições passeando com os alunos - e preparou uma coleção de manuscritos que se tomou modelo para as bibliotecas que surgiriam posteriormente. Organizou projetos de pesquisa, entre eles o estudo comparativo das 158 constituições gregas. Após a morte de Alexandre, em 323 , foi acusado de impiedade - sendo condenado à morte pelo Areópago - e abandonou Atenas, morrendo logo depois na Cálcida. Ele é modernamente considerado o pioneiro de muitos campos de investigação filosófica contemporâneos. Seus interesses eram de enorme amplitude e abrangiam quase todos os ramos da filosofia e da ciência natural. De sua extensíssima obra enciclopédica - seus tratados provêm de notas tomadas pelos seus alunos, assim, não foram redigidos por ele--, grande parte se preservou, principalmente na forma de conferências proferidas no Liceu, sua escola ou área de Atenas onde se reunia o grupo de filósofos ligados a ele, equivalente ao que fora a Academia, na época de Platão. Foi Aristóteles quem iniciou o estudo sistemático da lógica, desenvolvendo um sistema que permitisse a descrição formal e avaliação do raciocínio, e que perdurou até o século XIX como o núcleo da disciplina. O interesse de Aristóteles quanto às diferentes funções das palavras na língua está na origem do estudo moderno da gramática - dita de categorias -, o que faz dele um dos precursores da filosofia da linguagem e da linguística. Ainda hoje são objeto de debate as questões centrais abordadas por Aristóteles na obra Metafísica - "o que é substância?", "o que é próprio dos seres?" - e na obra Da Geração e Compup̧ão -. "como as coisas e seres passam a existir e deixam de existir?". Em sua obra A Respeito da Alma, discute o que é a alma - em grego psyché-, aquilo que dá aos seres vida e as atividades características da vida. Ao argumentar que a alma/psique depende do corpo, Aristóteles antecipa umlongo debate filosófico, presente até hoje nas teorias sobre a mente. A ética, como disciplina filosófica, ainda hje tem como marco a Ética de Aristóteles. O argumento de que toda ação tem por objetivo a eudaimonia, ou felicidade, tem afinidades com a moderna corrente do utilitarismo; no entanto, a ênfase dada por ele às diversas virtudes difere do esforço utilitarista em encontrar um princípio único - e mesmo simples - que oriente o juízo sobre todas as questões morais. Seu trabalho caracterizou-se pelo amor à ordem, aparente na cuidadosa classificação das diferentes áreas da ciência. O conjunto de suas obras costuma ser dividido em quatro partes: (I) obras de lógica - Onganon - que fundam a lógica formal, a teoria dos juizos e dos raciocínios; a conclusão é uma teoria do conhecimento: o primeiro momento do conhecimento é a percepção; é pela memória que passamos da percepção à experiência, a partir de lembranças repetidas; a experiências fixa as leis fundamentais; em nível mais elevado encontramos a arte e, enfim, a ciência; a passagem do particular para o universal faz-se por um processo de indução fundado em leis da razão; essa teoria do conhecimento, empírica em sua gênese, racional em seu fundamento, caracteriza o que se denominou depois por conceitualismo ou conceptualismo; (II) obras de filosofia natural - Das Partes dos Animais -, que através de observação empírica e racionalidade, comparam as diversas anatomias e fisiologias animais; (III) obras sobre cosmografia, física e metafísica - Do Céu, Física, Metafísica -, onde compõe um sistema físico vitalista, vale dizer, todos os seres são animados, sendo o movimento explicado por uma força interna - ou forma substancial - dos corpos, fugindo de uma explicação fundada numa razão externa, ou de fora do corpo - por exemplo, o choque mecânico -, para explicar o movimento, e essa dinâmica sistematizadora dos fenômenos se alicerça numa metafísica que explicaria a relação entre a forma e a matéria, e o ato e a potência; a metafísica fundaria física numa teologia, numa teoria de Deus - Deus como transcendente (como pensamento de pensamento), e Deus como imanente (vivente etemo perfeito), como motor do universo, como ato puro; (IV) obras sobre política e ética - Politica e Ética a Nicômaco -, que aliam os preconceitos das cidades gregas de então, frente a consideraçôes inovadoras e modemas - importância da prática em moral; papel do meio geográfico, econômico e social; idéia de uma ciência política baseada na experiência. Por fim, Aristóteles também escreveu sobre tetórica e poética política. Foi redescoberto pelos eruditos árabes e, traduzido para o latim, moldou o desenvolvimento do pensamento medieval tanto nas artes quanto na ciência. São Tomás de Aquino reconciliou as doutrinas aristotélicas comas da teologia cristã, e elas permaneceram parte fundamental da educação superior na Europa desde o século XIII até o século XVII. In: NOVA ENCICLOPÉDIA ILUSTRADA FOLHA. São Paulo: Empresa Folha da Manhã, 1996. v. 1; GRANDE ENCICLOPÉDIA LAROUSSE CULTURAL. São Paulo: Nova Cultural, 1998, v. 2. 
capacidades criadoras, ativas, inventivas dos agentes e da própria noção, poder gerador esse que não se confundiria com a idéia de um espírito universal, ou mesmo de uma natureza ou de uma razão intrínseca humana. ${ }^{39}$

O babitus ou hexis é um "princípio gerador e unificador que retraduz as características intrínsecas e relacionais de uma posição em um estilo de vida unívoco, isto é, em um conjunto unívoco de escolhas de pessoas, de bens, de práticas". ${ }^{40} \mathrm{~A}$ inserção de um agente ou grupos - classe de agentes - numa determinada posição no espaço social não é espontânea, tem a influência de que naquele ponto aonde irá se inserir se localiza um conjunto de agentes com semelhanças de estilo de vida, de bens desfrutados e práticas sociais. Por isso, uma das funções do habitus é dar conta dessa unidade de estilo de vida que vincula as práticas sociais e os bens desfrutados de um agente singular ou de uma classe de agentes. ${ }^{41}$

Os habitus, assim, são diferenciados e diferenciadores; distintos e distinguidos, eles são operadores de distinções, geradores de práticas distintas e distintivas - o que se come, o que se veste, como se fala, o que se fala, esportes que se pratica, etc. - "são esquemas classificatórios, princípios de classificação, princípios de visão e divisão e gostos diferentes", estabelecendo "diferenças entre o que é bom e mau, entre o bem e mal, entre o que é distinto e o que é vulgar (...) mas elas [esquemas classificatórios, habitus] não são as mesmas [definidos num sentido único e universal] (...) [pois] o mesmo comportamento ou o mesmo bem pode ser distinto para um, pretensioso ou ostentatório para outro e vulgar para um terceiro". ${ }^{42}$

Sua essencialidade está em que ao serem percebidas, as diferenças presentes e veiculadas tornam-se diferenças simbólicas e passam a constituir uma verdadeira linguagem, por sua vez constitutiva de um sistema mítico, como signos distintivos. $\mathrm{O}$ ser humano, desta forma, vive num dado ponto do espaço social em que ele difere e é diferente, e nessa distinção ele se significa; essa diferença só é percebida e torna-se pertinente por alguém capaz de estabelecer a diferença, sendo que, por esse princípio de visão e divisão que lhe é inscrito, ele se estrutura marcado conforme as diferenças. Considerando a totalidade dos agentes sociais e os grupos, tem-se que o que se sucede socialmente é produto dessa ação ou omissão marcantes, significativa e distintiva de forma cotidiana, e que ninguém consegue ser indiferente a esse fenômeno mas, ao contrário, sofre o influxo das condutas humanas marcadas pela significação na distinção. ${ }^{43}$

No campo científico - campo social específico de um conjunto de agentes sociais dedicados à ciência -, por exemplo, o babitus se manifesta na forma de um comportamento estratégico prático que não necessita do agente um cálculo racional para se posicionar no jogo; aí está o valor do habitus, o agente que é dele dotado - de acordo com o campo social onde

39 BOURDIEU, O poder..., p. 60-1.

40 BOURDIEU, Razões..., p. 21-2.

41 BOURDIEU, Razões..., p. 21.

2 BOURDIEU, Razões..., p. 22.

43 BOURDIEU, Razões..., p. 22-3 
atua - já tem o "sentido do jogo [do jogo social que é jogado nesse campo ou no espaço social determinado onde está atuando] e não tem necessidade de raciocinar para se orientar e se situar de maneira racional num espaço". O babitus ou hexis, assim, favorece uma tomada de posição vantajosa mesmo sem o agente raciocinar, pois ele condiciona tal atitude. ${ }^{44}$

Essa noção, assim, procura exprimir uma recusa a opções que a ciência social criou e se encerrou - consciência, inconsciência, finalismo, mecanicismo, etc. - para explicar as ações e atitudes humanas, inclusive romper com o tradicional paradigma estruturalista - que investe numa filosofia da ação calcada no inconsciente e reduzindo um agente a papel ou função de suporte da estrutura -, sem retornar, como opção inexorável - quando ocorre hiatos ou ausências teóricas substitutas ao se abandonar o estruturalismo -, à filosofia do sujeito ou da consciência, ou o bomo economicus da economia clássica.

A noção original retomada é hexis de Aristóteles, mas que a escolástica converteu em babitus, e ela põe em evidência as capacidades - poder gerador-criadoras, ativas e inventivas do habitus e do agente. Esse poder gerador não se identifica com um espírito universal, com uma dada natureza ou fruto de uma razão humana, mas fruto de um agente em ação na inter-relação com o mundo; o habitus oụ hexis é um conhecimento adquirido e também um capital - um haver, um crédito - e indica uma disposição ou postura que já está programada ou incorporada num agente, retomando o primado da razão prática ou o lado ativo do conhecimento prático, abandonados, respectivamente, pelas tradições idealista e materialista.

Verifica-se que os utilizadores da expressão habitus sempre tiveram a mesma intenção de manter o agente como operador prático na construção de objetos sociais no mundo, mas abandonando a filosofia da consciência, como se constata em Hegel, ${ }^{45} \mathrm{com}$ sua noção de etos equivalente a bexis, reintroduzindo disposições duradouras constitutivas de uma moral

44 BOURDIEU, O poder..., p. 62. Sobre essa facilidade de um agente já estar posicionado adequadamente num campo para agir e obter os melhores ganhos possiveis, vide abaixo o item sobre campo.

45 George Wilhelm Friedrich Hegel (1770-1831), filósofo alemão fortemente influenciado pelo romantismo que desenvolveu a filosofia idealista de Kant. Ele modificou a metafísica de Kant em dois pontos fundamentais: a) sustentou que a divisão, proposta por Kant, da realidade em duas esferas distintas, a do conhecivel e a do cognoscivel, era incoerente; b) além disso, introduziu a dimensão da história no cerne da filosofia. O sistema daí resultante - elaborado na Fenomenologia do Espírito, em 1807 - considerava o mundo como a evolução do espírito na direção de uma crescente racionalidade, à medida em que esse espírito atingia graus nunca antes alcançados de consciência de si. Esse processo deveria, segundo Hegel, ser entendido como dialético, supondo por isso uma forma lógica bem diferente da dedução: em vez de uma oposição absoluta entre erro e verdade, na dialética o erro faz parte do caminho para a verdade e cada estágio da história do espírito ou do conhecimento é função do processo em que uma tese ou afirmação é contraditada por uma antítese, resultando desse conflito uma síntese que supera ambas e que por sua vez é oposta a uma nova antítese, e assim sucessivamente. Hegel defendia uma concepção monista - mente e realidade exterior têm a mesma natureza -, para a qual a história é regida por leis necessárias e o mundo constitui um todo orgânico, e que foi expressa na célebre frase segundo a qual o. "racional é real". Assim, ele se propõe a estabelecer um sistema que repousa no projeto de "pensar a vida" - o modo de colocar o ser e o pensamento, opondo-os num primeiro momento e depois superando esta oposição - na medida em que o mundo, o conhecimento desse mundo e discurso pelo qual esse conhecimento se exprime são concebidos como o desenvolvimento do Conceito. Propondo-se a expor este desenvolvimento do Conceito, o sistema hegeliano engloba a totalidade: exterioridade e interioridade se juntam, do mesmo modo que sujeito e objeto, no Absoluto que é o nível do discurso. A dialética hegeliana, assim, é este procedimento por oposição e englobamento das oposições, tanto no plano do entendimento como no da história. A dialética não é um método que supõe as exterioridades do entendimento em relação ao objeto, nem reciprocamente, mas é o próprio movimento do Conceito, a própria vida do sistema, por que o Absoluto é o sujeito. Hegel escreveu também Ciência da Lógica (1812-6), Enciclopédia das Ciências Filosóficas (1817), Principios de Filosofia do Direito (1821). In: NOVA ENCICLOPÉDIA ILUSTRADA FOLHA. São Paulo: Empresa Folha da Manhã, 1996. v. 1; GRANDE ENCICLOPÉDIA LAROUSSE CULTURAL. São Paulo: Nova Cultural, 1998, v. 12 
realizada; em Husserl, ${ }^{46}$ com seu conceito de habitualität, também semelhante a habitus, reintroduzindo uma relação de cumplicidade ontológica com o mundo; em Mauss, ${ }^{47}$ reconhecendo a dimensão corporal da hexis como porte ou postura, utilizando a noção para designar o funcionamento sistemático do corpo civilizado; e também em outros como Heidegger ${ }^{48}$ e Merleau-Ponty, ${ }^{49}$ que sem empregarem a expressão também buscaram afastar-

46 Edmund Husserl (1859-1939), filósofo e lógico alemão que defendeu a concepção de que todo conhecimento reside no fato de uma visão, pela consciència, de uma essência, sendo essa a marca de sua filosofia, vale dizer, de tipo essencialista. Para ele, a consciência é determinada por uma intencionalidade; assim, os fenômenos dão-se à consciência numa série de sucessivos esboços: a consciência é o invariante que recebe e dá sentido à série de esboços. Após ter mostrado a elaboração dos significados no campo das idealidades lógico-matemáticas, Husserl buscou construir uma filosofia da vida e da percepção. In GRANDE ENCICLOPÉDIA LAROUSSE CULTURAL. São Paulo: Nova Cultural, 1998, v. 13.

47 Marcel Mauss (1872-1950), sociólogo e antropólogo francês que analisou as formas de trocas nas sociedades não-industriais revelando a dimensão simbólica do prestígio, excluindo a possibilidade de reduzi-lo a aspectos juŕdicos e econômicos; ao analisar a dádiva, estendeu aos domínios jurídicos e morais os fundamentos econômicos da mesma. Para ele, a dádiva, à maneira dos outros atos sociais, põe em questão a totalidade da sociedade e de suas instituições. In: GRANDE ENCICLOPÉDIA LAROUSSE CULTURAL. São Paulo: Nova Cultural, 1998, v. 16

48 Martin Heidegger (1889-1976), filósofo alemão discípulo de Edmund Husserl, expoente da corrente filosófica existencialista que procurou responder em sua principal obra, O Ser e o Tempo, a questão fundamental: o que é o ser?. Ele desenvolveu um novo vocabulário filosófico, no qual a metafísica e a epistemologia davam lugar à análise dos diversos aspectos da existência humana. In: NOVA ENCICLOPÉDIA ILUSTRADA FOLHA. São Paulo: Empresa Folha da Manhã, 1996. v. 1.

4) Maurice Merleau-Ponty (1908-1961), filósofo francês que influenciado pela fenomenologia husserliana destacou-se, entre outros, por escritos sobre o existencialismo [Costuma-se indicar por esse termo, desde 1930 aproximadamente, um conjunto de filosofias ou correntes filosóficas cuja marca comum não são os pressupostos e as conclusões (que são diferentes), mas o instrumento de que se valem: a análise da existência. Essas correntes entendem a palavra existência como o modo de ser próprio do ser humano enquanto é um modo de ser no mundo, em determinada situação, analisada em termos de possibilidade. A análise existencial é, portanto, a análise das situações mais comuns ou fundamentais em que o ser humano vem a encontrar-se. Nessas situações, obviamente, o ser humano nunca é e nunca encerra em si a totalidade infinita, o mundo, o ser, ou a natureza. Portanto, o termo existência tem significado completamente diferente de outros termos como consciência, espíito, pensamento etc., que servem para interiorizar ou, como se diz, tornar "imanente" no ser humano a realidade ou o mundo em sua totalidade. Existirsignifica relacionar-se com o mundo, ou seja, com as coisas e com os outros seres humanos, e como se trata de relações nãonecessárias em suas vátias modalidades, as situações em que elas se configuram só podem ser analisadas em termos de possibilidades. Esse tipo de análise foi possibilitada pela fenomenologia de Husserl, que elaborou o conceito de transcendência onde, segundo esse conçeito, nas relações entre sujeito cognoscente e objeto conhecido ou, em geral, entre sujeito e objeto (não só no conhecimento, mas no desejo, na volição etc.), o objeto não está dentro do sujeito, mas permanece fora, e dá-se a ele em "came e osso". Esse conceito manteve-se rigoroso na filosofia de Husserl e exerceu grande influência no existencialismo, para o qual as relações entre o ser-aí (isto é, o ente que existe, o ser humano) e o mundo sempre se configuram como transcendência. In: ABBAGNANO, Nicola. Dicionário de filosofia. São Paulo: Martins Fontes, 1998, p. 402.]. In: GRANDE ENCICLOPÉDIA LAROUSSE CULTURAL. São Paulo: Nova Cultural, 1998, v. 16. Sobre fenomenologia, a expressão quer designar inicialmente a descrição daquilo que aparece ao ser humano; outra forma de designá-la é tratá-la como a ciência que tem como objetivo ou projeto a descrição do que aparece - ou emerge apresentando-se - ao ser humano. Vários pensdores em diferentes épocas utilizaram a expressão dando diferentes sentidos espeć́ficos, inclusive no aspecto da psicologia descritiva. Foi Edmund Husserl quem fixou a noção até hoje presente e permanente sobre fenomenologia, dando um significado de fenômeno que implicou na eliminação da confusão entre psicologia e fenomenologia. Husserl afirmou que psicologia é a ciência de dados de fato, sendo que os fenômenos que ela considera são acontecimentos reais que, juntamente com os sujeitos a que pertencem, inserem-se no mundo espaço-temporal. Já a fenomenologia, que ele denomina por "pura" ou "transcendental", seria uma ciência de essências - portanto, eidética - e não de dados de fato, possibilitada apenas pela redựão eidética, cuja tarefa é expurgar os fenômenos psicológicos de suas características reais ou empíricas e levá-los para o plano da generalidade essencial. A redução eidética, vale dizer, a transformação dos fenômenos em essências, também é redução fenomenológica em sentido estrito, porque transforma esse fenômenos em irrealidades. Com esse significado, a fenomenologia constituiu-se como uma corrente filosófica particular, que pratica a filosofia como investigação fenomenológica, ou seja, valendo-se da redução fenomenológica e da époche - suspensão do juízo, consistente em não aceitar nem tefutar, em não afirmar nem negar algo, sendo o contrário dessa atitude o que se conhece por dogmatismo, que já parte do assentimento sobre alguma coisa (ainda obscura, segundo uma corrente filosófica antiga grega). Os resultados fundamentais a que esta investigação levou, em Husserl, podem ser resumidos da seguinte maneira: a) o reconhecimento do caráter intencional da consciência, em virtude do qual a consciência é um movimento de transcendência em direção ao objeto, sendo que o objeto, ao mesmo tempo, se dá ou se apresenta à consciência "em came e osso" ou "pessoalmente"; b) evidência da visão - intuição - do objeto devido à presença efetiva do 
se da filosofia da consciência. ${ }^{50}$

\subsection{A classe social}

Mas como Bourdieu constrói sua visão de classe na sociedade? Construir o espaço social realidade invisível e intangivel - é possibilitar a construção de classes teónicas homogeneizadas, através de um princípio de classificação que se torna também explicativo, vale dizer, descreve classificatoniamente o conjunto das realidades sociais - aquelas escolhidas como pertinentes, que no caso em tela trata-se de agrupar os agentes que mais se pareçam entre si e distinguir daqueles que sejam tão diferentes quanto possível pertencentes a outras classes - de acordo com algumas propriedades determinantes assinaladas, que acabam por permitir predizer outras propriedades porventura existentes ou não. ${ }^{51}$

Ocorre que a classificação assim procedida, construtora de classes teóricas, pode levar a indução de que o que existe antes de tudo teoricamente, possa existir realmente, como classes reais ou grupos reais. Ora, a pesquisa de agentes ou grupos e sua teorização em modelos inscrevem predições, previsibilidades, probabilidades, mas não significa que constituam necessariamente uma classe de acordo com o que Karl Marx" assinalou, "um grupo mobilizado por objetivos comuns $e$

objeto; c) generalização da noção de objeto, que compreende não somente as coisas materiais, mas também as formas de categorias, as essências e os "objetos ideais" em geral; d) caráter privilegiado da percep̧ão imanente, ou seja, da consciência que o eu tem das suas próprias experiências, porquanto nessa percepção aparecere ser coincidem perfeitamente, ao passo que não coincidem na intuif̧ão do objeto externo, que nunca se identifica com sua aparições à consciência, mas permanece além delas. In: ABBAGNANO, Nicola. Dicionário de filosofia. São Paulo: Martins Fontes, 1998, p. 339 e 437-8.

50 BOURDIEU, O poder..., p. 62.

51 BOURDIEU, Razões..., p. 24.

52 Karl Marx (1818-1883), cientista social, filósofo, teórico do socialismo e revolucionátio alemão. Segundo filho de um advogado liberal de confissão judaica convertido ao protestantismo, foi originalmente um dos discipulos de Hegel - com rompimento mais tarde -, tendo estudado Direito nas Universidasdes de Bonn e Berlim, onde aprofundo-se em História e Filosofia. Devido a seu radicalismo viu sua ambição de seguir carreira acađêmica em Bonn frustradas. Em 1841 preparou em Iena uma tese sobre As diferengas da filosofia da natureza em Demócrito e Epicun, que o fez descobrir a crítica materialista da religião. Membro dos jovens hegelianos, ligou-se aos irmãos Bauer e recebeu também a influência de L. Feurbach. Em 1842, em Colônia, tomou-se redatorchefe da Gazeta Renana, jomal de oposição fundado por burgueses radicais, que seria proibido de circular pelo censor. Foi então que tomou conhecimento dos problemas econômicos e conheceu melhor o socialismo francês, pela leitura de SaintSimon, Fourier, Proudhon etc. Casou-se com uma amiga de infância, Jenny von Wẹstphalen, em 1843, e mudou-se para Paris, onde lançou, após a interdição da Gazeta Renaana, os Anais Franco-Alemães, em cujo único número figura A questão judaica (1844). Em Paris encontrou Friedrich Engels, que se tomaria seu colaborador intelectual em diversos trabalhos. Hegel exerceu uma grande influência sobre os Manuscritos de 1843 e 1844, nos quais o jovem Marx desenvolveu uma filosofia onde a alienação é o tema central. Na mesma época Marx redigiu sua Contribuição à critica da filasofia do dineito de Hegel. Escreveu, contra os hegelianos, A sagrada família, com Engels (1845), a Ideologia alemä (1845, só publicada em 1932) e, contra Proudhon, Miséria da filosofia (1847). Em 1845, toi para Bruxelas, onde associou-se à Liga Socialista pela Justiça (1847), posterio mente denominada Liga Comunista. $O$ periodo vivido em Paris (1843-5) e depois em Bruxelas (1845-8) foi marcado por uma intensa atividade política. Marx multiplicou os contatos com os militantes operários e os emigrados alemães, uniu-se a Engels, fundou a Sociedade dos Operários Alemães de Bruxelas e, com Engels, estabeleceu uma verdadeira rede de correspondência comunista. Os dois escreveram, entre outros, o Manifesto do Partido Comunista (1848), solicitado pela Liga dos Comunistas. Esses foram seus anos de acerto de contas com sua conscièncai filosófica de outrora e da elaboração do materialismo histórico: a ruptura com seu passado foi tanto política quanto teórica. Quando as Revoluções de 1848 eclodiram, Marx foi expulso da Bélgica. Fixoul-se em Colônia, num breve retomo, onde lançou a Nova Gazeta Renana (junho de 1848 a maio de 1849), para a qual escreveu numerosos artigos em favor dos operários - Trabalbo assalariado e capital. Expulso da Alemanha e depois da França, refugiou-se em 1849 em Londres, onde viveu na miséria, atenuada pela ajuda financeira de Engels que viveu o resto de seus dias. Escreveu então Lutas de classes na Franga (1850). Dispô-se a estudar economia e concebeu sua obra-prima, O capital. Em 1864 foi convidado para assumir 
particularmente contra uma outra classe". ${ }^{53}$

Mas isso não significa que não possa haver classe no sentido marxista do termo, uma vez que a proximidade de agentes no espaço social define uma potencialidade objetiva de unidade, ou seja, uma classe provável, tornado-se necessário um trabalho político de mobilização para construir uma classe real pertinente a uma classe teórica. $O$ que se pode denominar mais proximamente por classe, real e concretamente - ou seja, no mundo contemporâneo e porque não de todas as épocas - , é talvez uma classe mobilizada ou realizada, resultado de uma luta simbólica política - de classificação que impõe uma visão do mundo social "ou, melhor, uma maneira de construí-la, na percepção e na realidade, e de construir as classes segundo as quais ele pode ser recortado"; enfim, tratar-se-ia aqui de uma classe de agentes que se impôs concretamente na realidade do mundo social e, assim, impõe a sua visão e divisão particular - exclusiva ou singular - de mundo a todos os demais agentes sociais. ${ }^{54}$

\footnotetext{
a direção da Associação Geral dos Operários Alemães - I Internacional -, para a qual redigiu o Discurso inaugurale os Estatutos. Estando em Paris por ocasião da Comuna, deu-lhe uma interpretaçaõ militante em A guerra civil na Franģa (1871). Continuou a redação de $O$ capital, participando ativamente da definição dos programas dos partidos operários alemão - Critica do Programa de Gotha - e francês - Consideraģnes sobre o programa do Partido Operário Francês, 1880. Auxiliou Engels na rdação de Anti-Dubring (1878), mas, devido a sua doença, à morte de sua mulher (1881) e de sua filha Jenny (1883), não resistiu, vindo a falecer a 14 de março do mesmo ano. Seu envolvimento, como jornalista, com os grupos radicais alemães e franceses da conturbada década de 1840 levou-o adotar o comunismo e a formular uma ampla e influente crítica do capitalismo, por ele condenado como a maior causa da alienação humana moderna. Convencido da importância central da economia - isto é, das condições materiais de vida - para a determinação dos demais apsectos da existência humana, Marx inverteu a célebre fórmula idealista de Hegel, segundo a qual é a consciênica, ou o espírito, que determina o curso da história humana; desenvolveu, nesse sentido, uma interpretação materialista da história, que no entanto conserva da doutrina de Hegel a noção de dialética, a qual se transformaria no núcleo da corrente filosófica, ideológica e político-social conhecida como marxismo. Marx previa uma revolução política e social global, como resultado de um conflito entre as classes trabalhadoras e os capitalistas, os quais usavam o Estado para reforçar seu próprio domínio. Sua meta exa a união de todos os trabalhadores para conseguirem o poder político. Após a militância revolucionária e as obras de caráter político e histórico, nos últimos anos de sua vida Marx dedicou -se mais intensamente às análises econômicas, com o propósito de demonstrar o caráter essencialmente exploratónio do capitalismo, que, segundo ele, fazia com que o sistema produzisse crises cada vez mais graves. Seus estudos resultaram na obra 0 capital, de 1867 - editada por Engels em 1885-94. Durante muitas décadas, $O$ capital foi uma referência central na área das ciêncais sociais. Em seus escritos anteriores, de cunho mais jomalístico, Matx analisou os acontecimentos políticos de sua época a partir de uma perspectiva comprometida com a classe operária. Em várias ocasiões participou ativamente de movimentos socialistas, ajudando a fundar a Primeira Internacional, em 1864, sendo escolhido seu líder. Um choque ideológico entre Marx e Bakunin levou-os a se desentenderem em 1876. Desde sua morte, sua extensa obra exerceu imensa influência sobre o pensamento político e social, e, mais especificamente, sobre os movimentos e partidos socialistas do mundo todo. Assim, durante a vida escreveu diversas obras objetos de muitas referencias, tendo, juntamente com Friedrich Engels (1820-1895), concebido o marxismo como uma concepção sistemática social de idéias econômicas e política, desenvolvido, posteriormente, por seus adeptos. O marxismo, com seu materialismo dialético, é a base teórica e prática do comunismo; no cerne do marxismo encontra-se a concepção materialista da história, de acordo com a qual o desenvolvimento de todas as sociedades é, em última instância, determinado pelos métodos de produção adotados pelo povo para atender às suas necessidades. Uma técnica particular de produção determina, em primeiro lugar, um conjunto de relações de propriedade para organizar a produção - escravidão, feudalismo, capitalismo -, e, em segundo lugar, a política, a religião ou a filosofia de uma determinada sociedade. Desta forma, é o conflito entre as classes emergentes - luta de classes - que leva ao estágio seguinte da evolução social. $O$ feudalimso é sucedido pelo capitalismo e será, por sua vez, sucedido pelo socialismo/comunismo. In: GRANDE ENCICLOPÉDIA LAROUSSE CULTURAL. São Paulo: Nova Cultural, 1998, v. 16; NOVA ENCICLOPÉDIA ILUSTRADA FOLHA. São Paulo: Empresa Folha da Manhã, 1996. v. 2.

53 BOURDIEU, Razões..., p. 24-5. Itálicos no orignal

54 BOURDIEU, Razões..., p. 25-6.
} 
Sabe-se que a existência de classes na teoria e na realidade é alvo direto de lutas. Uma tradição procura negar a existências de classes, em realidade procurando negar, no limite, a existência de diferenças e de princípios de diferenciação sociais; entretanto, mesmo em países muito desenvolvidos, onde a maioria se considere homogeneamente pertencentes a uma mesma classe identificada com alto bem-estar sócio-econômico e participação democrática, pesquisas revelam que a diferença se encontra por todos os espaços, revelando assim que a diferença existe e persiste vigorosamente no espaço social. Diante disso, melhor que afirmar a existência de classes sociais, seria admitir que o "que existe é um espaço social, um espaço de diferenças, no qual as classes existem de algum modo em estado virtual, pontilhadas, não como um dado, mas como algo que se trata de fazer". ${ }^{5}$

Uma importante conclusão emerge. $\mathrm{O}$ mundo social, com suas diferenças e divisões, apresenta-se como algo que os agentes sociais continuamente têm que construir individual e coletivamente, tanto na cooperação quanto no conflito, e a posição ocupada por cada qual no espaço social - na estrutura de distribuição de diferentes tipos de capital - governa não só as representações desse espaço mas também a iniciativa de tomadas de posição nas lutas para conservá-lo ou transformá-lo. Assim, nessa relação complexa entre estrutura objetiva e construções subjetivas, parafraseando Blaise Pascal, ${ }^{56}$ o sociólogo francês assinala que o "espaço social me engloba como um ponto. Mas esse ponto é um ponto de vista, princípio de uma visão assumida a partir de um ponto situado no espaço social, de uma perspectiva definida em sua forma e em seu conteúdo pela posição objetiva a partir da qual é assumida. O espaço social é a realidade primeira e última já que comanda até as representações que os agentes sociais podem ter dele". ${ }^{57}$ Ter consciência dessa realidade objetiva e fenomênica não altera nada por si, mas principiam reflexões sobre as "armas" passíveis de uso para conservações e transformações necessárias nesse espaço, compreendendo-se as imbricações entre a estrutura objetiva e as construções subjetivas nesse processo.

Entretanto, a expressão "estrutura social", comumente empregada pelos sociólogos para identificar uma sociedade estratificada com classes ou grupos de status, ${ }^{58}$ se efetivamente forma uma estrutura, torna preciso compreendê-la em que medida tais partes mantêm relações entre si para além de uma mera justaposição e se isso realmente está sucedendo factualmente no espaço social, vale dizer, se propriedades são reveladas como resultantes de uma dependência da classe ou grupo de status com relação à totalidade que os define. $\mathrm{O}$ termo "estrutura social" normalmente quer designar ou substituir a expressão "organização social", entretanto, mais precisamente procura-se vincular a expressão "estrutura" com um sistema de posições sociais, ao passo que a expressão "organização" direciona-se para designar

\footnotetext{
55 BOURDIEU, Razões.., p. 26-7. Itálicos no original. O autor também cita Edward Palmer Thompson e sua obra "A Formação da Classe Operária Inglesa", editada no Brasil pela Editora Paz e Terra, sobre o sentido que dá para construção ou fabricação de uma classe no sentido marxista. In: BOURDIEU, Razões..., p. 29.

56 Blaise Pascal (1623-1662), matemático, físico, flósofo religioso e homem das letras francês. In: NOVA ENCICLOPÉDIA ILUSTRADA FOLHA. São Paulo: Emptesa Folha da Manhã, 1996. v. 2.

57 BOURDIEU, Razões..., p. 27.

58 Grupo de status é um conceito weberiano que quer significar um conjunto de pessoas definidas por uma certa posição
} 
um sistema de papéis sociais. ${ }^{59}$

A noção de estrutura social pressupõe que cada classe social - historicamente construída e definida, ocupante de uma posição e por essa posição afetada nas relações com as outras partes constitutivas da estrutura - possui propriedades marcantes de posição justamente por estar integrada numa estrutura e, como tal, um elemento nela constituinte e determinado, sendo essas propriedades independentes de propriedades intrínsecas evidenciadas como com a prática profissional e condições materiais de existência, estes últimos mais relacionados com os papéis sociais - sua situação ou condição de classe - que exercem. A distinção entre propriedades de posição e propriedades de situação é eminentemente uma operação do intelecto humano, e parte do pressuposto acima referido e da necessidade de desvelar - afastar ignorâncias - as determinações específicas que uma classe socral recebe do conjunto total de relações que ela estabelece com as outras classes, levando a ser estabelecida identificações verdadeiras e analogias reais. ${ }^{60}$

As propriedades de posição permitem negativamente, vale dizer, impedem que um sociólogo transfira imediatamente, de uma sociedade à outra, esquemas interpretativos - descritivos e explicativos - ou, referido à mesma sociedade, mas de uma época a outra. Verifica-se que duas classes ou duas sociedades diferentes, mesmo quando definidas por condições de existência ou práticas profissionais idênticas ou semelhantes, apresentam propriedades diferentes quando inseridas em estruturas sociais diferentes e por acabarem ocupando posições estruturalmente diferentes. Por outro lado, se duas classes ou dois grupos, caracterizadas por condições de existência e práticas profissionais diferentes, apresentarem propriedades comuns devido ao fato de ocuparem posições semelhantes em duas estruturas diferentes, isso não permite estabelecer imediatamente, e por si só, proposições gerais, trans-culturais e trans-históricas, a partir de casos isolados do contexto histórico e social que estão inseridos. Uma comparação é feita atendo-se às estruturas, mais que aos seus elementos; estruturas equivalentes e partes estruturalmente equivalentes das mesmas permitem efetuar uma proficua comparação. ${ }^{61}$

Somente nesse sentido estruturas sociais de duas sociedades diferentes podem apresentar propriedades estruturalmente equivalentes, mesmo verificando-se diferenças profundas quanto às características objetivas das classes que a constituem e compõem. Essa apreensão estrutural permite submeter cada classe social a um questionamento e investigação mais sistemático e metódico, para desvelar verdades que uma apreensão "realista" - a realidade social tal com se apresenta imediatamente

\footnotetext{
hierárquica de honra e de prestígio, diferentemente de classe social que, para Weber, quer significar um grupo de indivíduos que compartilham as mesmas chances típicas no mercado de bens e trabalho, as mesmas condições de existência e de experiências pessoais - enfim, que partilham a mesa situação de classe ou situação de mercado. In: BOURDIEU, Pierre. A economia das trocas simbólicas. 5. ed. São Paulo: Perspectiva, 1998, p. 14

59 BOURDIEU, A economia das trocas simbólicas, p. 3 e notas de rodapé n. 1 e 2

๑ BOURDIEU, A economia das trocas simbólicas, p. 3-4

61 BOURDIEU, A economia das trocas simbólicas, p. 5-6
} 
aos sentidos e percepção, enfim, sociologia espontânea - não poderia indicar. Nesse sentido, como exemplo de propriedades de posição, análises de Werner Sombart ${ }^{62}$ e Max Weber ${ }^{63}$ revelaram que há um ressentimento, disfarçado sob o discurso da indignação moral, ligado historicamente a uma posição de inferioridade na estrutura social, especificamente pertinentes às camadas inferiores das classes médias. Por outro lado, como exemplo de propriedades de situação, é possível asseverar proposições que são aplicáveis aos grupos definidos não por sua posição social, mas por sua situação social, como a dos sub-proletários que, por sua insegurança econômica permanente, acabam por não se constituir como um corpo coerente de reivindicações sociais e econômicas. ${ }^{64}$

Outro fator significativo de análise é que a posição de um indivíduo - agente social ou de um grupo dentro de uma estrutura social somente pode ser avaliada dinamicamente - jamais estaticamente, como é feito erroneamente ao enquadrá-lo simplesmente numa posição superior, média ou inferior na estrutura social - e circunstancialmente. Todo grupo ou indivíduo localizado numa dada posição da estrutura social, possui uma trajetória social - histórica - que está se realizando; portanto, há propriedades sociais que podem ser extraídas da posição - caminhar já feito ou realizado da trajetória social - e do futuro que a posição indica para o indivíduo ou grupo. Conclui-se que posições aparentemente idênticas podem se revelar diferentes quando comparados ao futuro histórico da posição ocupada por cada um, enfim, ao destino de cada qual dentro da estrutura social vista em conjunto. Por outro lado, o sentido ascendente ou descendente do futuro trajeto de cada qual podem ser a propriedade comum desses grupos ou indivíduos, mesmo não tendo a mesma trajetória social - o mesmo caminhar social - já realizado. ${ }^{65}$

A classe burguesa junto com as demais outras classes relativas que conviviam com ela - ou ela com as outras classes - como a classe nobre - por terras, títulos ou profissốes eruditas - e a classe ou grupo que reunia camponeses iletrados, pequenos artesãos, e trabalhadores não-qualificados, é exemplo de classe social que ocupa - ou ocupou - a mesma posição em estruturas sociais diferentes e que apresenta um certo número de propriedades comuns, mesmo verificando-se diferenciação significativa de sua situação social. Assim, a análise estrutural das sociedades e seus grupos na Inglaterra, França, Alemanha e Itália, revela que essa classe média - ou intermédia que essa análise consagrou historicamente como burguesa, construiu e manteve traços

Q. Werner Sombart (1863-1941), economista alemão que, entre outros, estudou as motivações subjetivas dos agentes econômicos. In: GRANDE ENCICLOPÉDIA LAROUSSE CULTURAL. São Paulo: Nova Cultural, 1998, v. 22.

63 Max Weber (1864-1920), sociólogo alemão e um dos fundadores clássicos da sociologia. Estudou e escreveu resultados de pesquisas sobre assuntos múltiplos, da historia da economia à sociologia da música; afirmou que havia um elo entre a emergência do protestantismo e a ascensão do capitalismo, tendo sido um dos pioneiros a dar importância para a burocracia num meio social, ligando-o a determinado tipo de poder social institucionalizado. Ao estudar a estratificação social, revelou que pertencer a uma classe social não dependia diretamente de atributos econômicos ou ocupacionais, mas também do status - ou estatuto de reconhecimento ou prestígio social - no seu papel para a desigualdade social; para ele a sociologia deveria interpretar e explicar o comportamento social, numa postura científica diversa das descrições e observaçóes preconizadas pelo positivismo comtiano. In: NOVA ENCICLOPÉDIA ILUSTRADA FOLHA. São Paulo: Empresa Folha da Manhã, 1996. v. 2.

64 BOURDIEU, A economia das trocas simbólicas, p. 6-7.

(5) BOURDIEU, A economia das trocas simbólicas, p. 7-8. 
comuns trans-históricos e trans-culturais como: (I) preocupação quanto ao seu lugar na ordem social; (II) espírito rigoroso de trabalho, esforço, seriedade, moderação e poupança; (III) estilo de vida; (IV) ethos e atitudes em relação à educação e à cultura; entre outros. ${ }^{66}$

Observa-se, também, que tais valores se irradiaram e acabaram por se manifestar em camadas baixas da pequena burguesia como empregados, funcionários médios e subalternos, que em suas atitudes e comportamentos profissionais - apego às práticas burocráticas, por exemplo - e pessoais - regularidade comportamental, probidade, rigor e indignação moral - retraduziram o novo sistema de valores conforme sua específica condição de vida ${ }^{67}$

Assim, verifica-se que as características das diferentes classes sociais estão em função da posição diferencial ocupada por cada classe na estrutura social e do seu peso funcional ${ }^{68}$ na mesma, proporcional à contribuição das classes para a constituição da estrutura, não se restringindo à uma questão de importância numérica. Mas além disso, tendo em vista que os membros das diferentes classes sociais estão continuamente estabelecendo e se envolvendo em relações simbólicas ${ }^{69}$ entre si, deliberadamente ou objetivamente verificáveis, decorre daí que muita das propriedades de uma dada classe provém - além de sua situação e posição na estrutura social - também dos resultados dessas interações e inter-relacionamentos efetuados pelos indivíduos ou agentes sociais. ${ }^{70}$

Essas relações simbólicas acabam exprimindo "diferenças de situação e de posição segundo uma lógica sistemática, tendendo a transmutá-las em distinções significantes. É a independência relativa do sistema de atos e procedimentos expressivos (...), das marcas de distinção, graças as quais os sujeitos sociais exprimem, e ao mesmo tempo

6 BOURDIEU, A economia das trocas simbólicas, p. 8-10.

G BOURDIEU, A economia das trocas simbólicas, p. 10-2.

8 O funcionalismo é um ramo de análise em ciências sociais e refere-se a uma orientação metodológica e teórica em que as conseqüências de um dado conjunto de fenômenos empíricos constituem o centro da atenção analítica, deixando de lado as causas dos referidos fenômenos. A expressão funcionalismo tem sido aplicada a toda uma variedade de abordagens divergentes, mas o elemento que estas têm em comum é a concentração nas relações de uma parte da sociedade com outra e de uma parte da sociedade com a sociedade inteira. In: OUTHWAITE, William; BOTTOMORE, Tom; et alii. Dicionário do pensamento social do século XX. Rio de Janeiro: Jorge Zahar, 1996, p. 326

๑) Simbolismo, simbólico, simbólica, símbolo, entre outros, são termos que querem expressar o uso dos signos e suas manifestações para o ser humano. O símbolo é o mesmo que signo, e quer designar - genericamente - qualquer objeto ou acontecimento, usado como menção de outro objeto ou acontecimento. Em sentido mais restrito a noção deve ser entendida como a possibilidade de referência de um objeto ou acontecimento presente a um objeto ou acontecimento não-presente, ou cuja presença ou não-presença seja indiferente; um ente do qual se infere a presença ou a existência passada ou futura de outro ente. Os símbolos revelam alguma coisa ou são indicativos de algo que é obscuro, e são um produto intelectual que é uma relação de referência entre dois termos conexos e que permite chegar a conhecer alguma coisa. Distingue-se no signo a relação de significação e suposição que está implícito em seu uso, sendo que a vida humana está repleta de formas simbólicas com seus significados conceituais. Mais modernamente os signos foram estudados sob ponto de vista da sua relação com seus intérpretes, vale dizer, o uso que é dado aos signos; desse ponto de vista o signo é estudado como uma relação com ele próprio, com seu objeto e com o interpretante. In: ABBAGNANO, Nicola. Dicionário de filosofia. São Paulo: Martins Fontes, 1998, p. 894-6 e 901. A semiótica, no pensamento a partir do século XX, refere-se às teorias de signos e sistemas de signos, em especial com o seu papel na comunicação, portanto, ao estudo de sistemas de comunicação humana. Ela confere prio ridade à linguagem ou ao código lingüístico que é usado como paradigma de outros signos não-língüísticos de microfenômenos e macrofenômenos culturais. In: OUTHWAITE, William; BOTTOMORE, Tom; et alii. Dicionário do pensamento social do século XX. Rio de Janeiro: Jorge Zahar, 1996, p. 683.

70 BOURDIEU, A economia das trocas simbólicas, p. 12-4. 
constituem para si mesmos e para os outros, sua posição na estrutura social (e a relação que eles mantêm com esta posição) operando sobre os "valores" (no sentido dos lingüistas) necessariamente vinculados à posição de classe, uma duplicação expressiva que autoriza a autonomização metodológica de uma ordem propriamente cultural'". Essa ordem econômica e social, assim expressa sistematicamente pode, desta forma, ser legitimamente constituída e tratada como sistema e, conseqüentemente, tornar-se objeto de uma apreensão estrutural, onde as diferenças de segunda ordem como as marcas de distinção-expressando valores de posição vinculados a cada posição (nível) na estrutura social - dependem das atitudes que os agentes desenvolvem e adotam - educação vinculada à sua condição e posição na estrutura social - para apropriar-se dessas marcas simbólicas de valores. ${ }^{72}$

\subsection{Os diferentes tipos de capital circulante no meio social}

A idéia de capital está diretamente ligada à idéia de campo. ${ }^{73}$ Cada campo constitui um tipo específico de capital e esse capital é uma espécie específica de capital simbólico. $\bigcirc$ capital simbólico não se confunde com o capital econômico, como normalmente é relacionado a expressão "capital"; trata-se de um fundo ou riqueza específica e singular-socialmente definido e reconhecido - que angaria um agente ou instituição num dado campo. Isso resulta por lhe reconhecer uma competência - por seus atos é que se dá o conhecimento e reconhecimento dos valores e objetos eleitos com importantes e lucrativos do ponto de vista social, por seus diversos protagonistas, num dado estágio do campo - produtora de efeitos, uma determinada autoridade, e que contribui para definir as regras do jogo do campo específico e a leis que garantem os lucros sociais para os diversos protagonistas em luta nele - no campo científico, por exemplo, define o que pode ser considerado como é brilhante ou antiquado, sobre que tema escrever, onde publicar. Desta forma, por exemplo, o capital científico - tipo especifico de capital - seria uma espécie de capital simbólico consistente em reconhecimento - ou crédito - outorgado a alguém ou uma instituição pelo conjunto dos pares-concorrentes dentro do campo científico, se revelando através de citações, prêmios, medalhas, traduções, etc. ${ }^{74}$

\footnotetext{
71 Para os lingüistas, a significação de um signo não pode ser confundida com o significado do mesmo. O significado é o conceito ou imagem que vem junto e acompanhado do significante e a significação é a união efetiva entre um certo significado e um certo significante, revelando-se no âmbito da fala, e revelando ser sempre uma questão individual e localizada no tempo e no espaço. Nesse sentido, também não pode ser confundido significação com valor de um signo; valor de um signo é tudo que está à volta do signo, em seu entomo, e que ajuda a determinar a significação do mesmo. Por exemplo, a expressão "tutu" tanto pode remeter a um prato culinário típico à base de feijão, como pode temeter à significação dinheiro, sendo que o entomo do signo - com sua carga valorativa - irá determinar a significação correta para a ocasião. In: COELHO NETTO, J. Teixeira. Semiótica, informação e comunicação. 3. ed. São Paulo: Perspectiva, 1990, p. 22-3.

72 BOURDIEU, A economia das trocas simbólicas, p. 14

73 Um campo é um espaço social definido, com seus agentes e instituições que nele atuam, com seus valores, regras e autonomia própria Trata-se de um espaço social qualificado, cuja inter-relação entre os seus diferentes protagonistas definirá uma esfera cultural específica - economia, direito, filosofia, literatura, artes, música, etc. - e as ações e teações dos diferentes protagonistas do campo.

74 BOURDIEU, Los usos..., p. 79-80.
} 
A noção de capital nasce da necessidade de escapar de uma redução do mundo social como um encadeamento ou somatória de equilíbrios instantâneos e mecânicos entre agentes sociais - através de suas ações ou comportamentos -, onde eles estariam jogando um jogo ocupando um papel social de meros elementos intercambiáveis entre si, num mundo concebido como de concorrência perfeita, igualdade de oportunidades perfeita, sem inércia, sem acumulação, e sem transmissão hereditária de posses e caracteres adquiridos, onde cada momento é perfeitamente independente do anterior e vigoraria a idéia de que qualquer um pode alcançar seus objetivos imediatamente, vale dizer, em todo momento qualquer pessoa pode converter-se naquilo que se propõe a ser; num mundo social mecânico de liberdade e igualdade da forma acima descrita, a vida seria como um jogo de azar, onde a cada momento poder-se-ia ter uma surpresa. ${ }^{75}$

Entretanto, verifica-se que o mundo social é uma história cumulada, e dentro de um sentido mais amplo de economia das práticas sociais - economia essa que não se reduz à economia economicista como comumente é conhecido e pensado - há capital circulando por toda sociedade, diferentes tipos de capital, e esse capital é objeto de acumulação histórico-cultural de forma a produzir efeitos específicos no seio da sociedade, bem como nas trocas - intercâmbios - que são feitas diutumamente entre os diferentes agentes sociais. Esse capital - aqui ainda tratado genericamente é um trabalho acumulado, um bem, um patrimônio social que existe em forma material - como substância - ou em forma interiorizada ou incorporada - portanto, imaterial, invisível. Quando agentes sociais - indivíduos ou grupos - se apropriam desse capital de maneira privada ou exclusiva, o que estão possibilitando para si, efetivamente, é a apropriação da energia social em forma de trabalho vivo ou de trabalho coisificado, graças ao que encerra o referido capital. ${ }^{76}$

Esse capital acaba atuando de duas formas na sociedade, quais sejam, como força ínsita e como lei - norma -ínsita. Verifica-se, assim, que o capital é uma força inerente às estruturas sociais objetivas - como existem e se apresentam - e subjetivas - como são percebidas -, mas ao mesmo tempo atuam e funcionam como um princípio social fundamental para estabelecer as regularidades internas - pôr o mundo social dentro de uma "normalidade aceitável" - do mundo social. O mundo, assim, não existe e funciona, como não é fruto, de uma incerteza ou um jogo social comparável ao jogo de azar, jogado entre os agentes e grupos de agentes sociais, passível de ser traduzido por um simples olhar das ações e comportamentos - intercâmbios estáticos entre os diferentes agentes e grupos de agentes, como se um conjunto de retratos tivesse sido tirado deles - num determinado momento - e os referidos retratos pudessem revelar o caminhar do mundo social naquele momento; enfim, o mundo social não é o local onde ingenuamente se compreenderia que o estatuto social a ser alcançado estaria sempre em aberto e presente, à disposição de quem simplesmente desejar possú-lo. Constata-se que não se ganha um estatuto social em curto espaço de tempo, também não se perde ele de um

\footnotetext{
T5 BOURDIEU, Pierre. Poder, derecho y clases sociales. 2. ed. Bilbao: Desclée de Brouwer, 2001, p. 131-2

76 BOURDIEU, Poder, derecho..., p. 131
} 
momento para outro automaticamente; a acumulação do capital em suas forma objetivada ou incorporada requer tempo. É insita do capital sua tendência para a sobrevivência, podendo produzir benefícios - benefícios esses que revelam essa forma particular de sobreviver, convertendo-se ou transformando-se em outra coisa -, mas também reproduzindo-se a si mesmo, inclusive crescendo. ${ }^{77}$

O capital é uma força inscrita na objetividade das coisas, sendo que determina que nem tudo no mundo social seja possível e impossível. Como uma força inscrita objetivamente nas coisas do mundo social, o capital está dotado de uma inércia portanto com seu peso específico tendendo a manter certas coisas no mundo -, e esta inércia das estruturas do capital acaba guardando relação com o fato de que essas mesmas estruturas se reproduzem geralmente no marco das instituições sociais e disposições dos agentes, que são, por sua vez, produtos das estruturas do capital, portanto, se encontrando adaptados - "naturalmente" - a estas estruturas. A referida inércia também se vê reforçada mediante uma ação calculada, especificamente políticoconservadora, qual seja, através de uma política de desmobilização e despolitização social, voltada para manter os agentes dominados numa situação de grupo meramente prático - diferentemente de um estatuto de grupo político -; de tal modo isso é feito, que esses agentes sociais, ao final, apenas entram em contato uns com os outros mediante a condução pré-direcionada das suas disposições, e resultando condenados a atuarem como um agregado de agentes - e não como um corpo unitário - limitandose a práticas sociais - especialmente políticas - isoladas e conservadoras - que preservam o status quo - de cunho sempre idênticas, tais como as decisões eleitorais ou de consumo. Assim, a estrutura de distribuição dos diferentes tipos e subtipos de capital, dada num momento determinado do tempo, corresponde à estrutura imanente do mundo social, vale dizer, corresponde à totalidade de forças que lhe são inerentes, mediante as quais se determina o funcionamento duradouro da realidade social e se decidem as oportunidades de êxito das práticas sociais. ${ }^{78}$

De fato, não é possível ter uma visão completa da estrutura e funcionamento do mundo social, a não ser que seja reintroduzido nele o conceito de capital em todas as suas manifestações, não somente na forma reconhecida pela teoria econômica, uma vez que a teoria econômica considera todas as formas de troca social, que não aquelas que ela abarca, como relações não econômicas e desinteressadas. $O$ mundo social, e as práticas que nele se desenvolvem - e o marcam -, necessita de uma ciência geral da economia das práticas sociais, onde as trocas mercantis seja considerada apenas um caso particular entre todas as diversas outras formas possíveis de intercâmbio social. Nesse sentido, o capital pode apresentar-se em três formas fundamentais num espaço social, observando-se que a forma concreta em que se manifestará dependerá do campo de

\footnotetext{
7 BOURDIEU, Poder, derecho..., p. 131-2.

73 BOURDIEU, Poder, derecho..., p. 132-3 e nota de rodapé n. 1.
} 
aplicação correspondente, assim como o seu maior ou menor custo de transformação, que constituirá uma condição prévia para seu surgimento efetivo no campo específico: (I) o capital econômico é aquele que é direta e imediatamente convertível em dinheiro e resulta indicado especialmente para a institucionalização, em forma de direitos de propriedade, em curso na sociedade; (II) o capital cultural é aquele que pode converter-se, sob certas circunstâncias, em capital econômico e resulta efetivamente apropriado para a institucionalização, sobretudo em forma de títulos acadêmicos, em curso na sociedade; (III) o capital socialé um capital de obrigações e relacionamentos sociais e que resulta, igualmente, e sob certas condições, ser convertido em capital econômico, podendo ser institucionalizado na forma de títulos nobiliários. Nesse contexto, o capital simbólico é capital - na forma que se encontre manifestado socialmente - na medida em que é representando, vale dizer, simbolicamente apreendido numa relação de conhecimento, mais precisamente, numa relação de simultânea de reconhecimento e desconhecimento, pressupondo a intervenção do babitus - capacidade cognitiva socialmente constituída - para sua manifestação. ${ }^{79}$

\section{O pensamento de Pierre Bourdieu enquanto epistemologia para aplicar às relações internacionais}

As investigações desenvolvidas pelo sociólogo francês permitem refletir sobre o mundo social - e o que se constrói enquanto realidade nesse universo - a partir das práticas históricas e culturais humanas; o mundo social é o que as pessoas fazem. De fato, o ser humano em conjunto, num determinado espaço e submetido à determinação do tempo, constrói realidades ou materialidades culturais e civilizatórias, vale dizer, fazem a vida ou existência individual e social de cada um ser concreta enquanto ganhos, perdas, possibilidades, felicidades, reconhecimentos, abandonos, desmerecimentos etc. a partir daí - fazem a vida acontecer conforme arbitrariamente se impôs. Um habitus resulta dessa convivência e produz e reproduz, sempre se renovando e sempre mantendo, o mundo social e suas práticas cotidianas em diversas esferas de sua existência; habitus é intrínseco à existência coletiva humana, assim como a ideologia. No fundo, sempre permanece a pessoa humana como fonte do que sucede socialmente, no plano interno de uma sociedade nacional ou no plano externo de diferentes sociedades nacionais; em realidade, este último, um mesmo plano da existência coletiva humana, vista de ângulo ou vista diferente.

\subsection{Reflexões sobre o pensamento de Pierre Bourdieu}

É preciso destacar vários aspectos elencados acerca do pensamento e estudos feitos por Pierre Bourdieu, e que atuam como um guia para se pensar a ação científica na busca da interpretação do mundo da natureza social do ser humano, vale dizer,

\footnotetext{
ToURDIEU, Poder, derecho..., p. 133-6 e nota de rodapé n. 4.
} 
para o caso específico deste trabalho, refletir cientificamente sobre a busca de verdades que traduzam o que sucede em diversas dimensões sociais, enfim, explicar até que ponto há condicionamentos produzidos por esse próprio ambiente social sobre o que ele produz individual e mesmo coletivamente e socialmente.

Em primeiro lugar, surge a necessidade de compreender como Bourdieu constrói o mundo social, vale dizer, seus diferentes campos, suas lutas, os poderes ou capitais que aí se estabelecem e as classes que aí se posicionam, enfim, o jogo social das distinções sociais, revelando nesse conjunto de atos e procedimentos científicos, também a sua maneira distinta de enxergar a composição do mundo social, a forma como ele teoricamente o constrói e de que forma ele contesta e complementa a visão de outros autores importantes das ciências sociais que se debruçaram sobre os mesmos ou diferentes objetos.

Desta forma, percebe-se que suas descobertas-propõem modos controlados e constantes de agir e de pensar e que constituem um método para a busca da representação realista da ação humana, enfim, uma explicação teórica - racionalização - que explica fundadamente as diferentes ações e comportamentos humanos do ponto de vista de ingerências socialmente pertinentes, transformando um conjunto complexo de dados sociais - ações, omissões, atitudes, disposições etc. - em esclarecimentos coerentes e razoáveis conforme suas pesquisas e reflexões constroem; tudo isso, para o pensador, é condição primeira para um conhecimento científico do mundo social em suas várias dimensões. Para ele a análise sociológica passa a ser um dos instrumentos poderosos para conhecimento de alguém próprio, como um ser social e, desta forma, como um ser singular, pois ela acaba por oferecer alguns dos meios mais eficazes de acesso à liberdade que o conhecimento dos determinismos sociais permite conquistar contra esses mesmos determinismos, conforme assinalou.

Ter consciência dessa realidade objetiva e fenomênica não altera nada por si, mas principiam reflexões sobre as armas ou instrumentos passíveis de uso para conservações e transformações necessárias nesse espaço, compreendendo-se as imbricações entre a estrutura objetiva - o que o social construiu como determinante e que influi concretamente nas opções de comportamento dos agentes - e as construções subjetivas - aquilo que o agente possui dentro de si como consciência do social e sua posição dentre dele - nesse processo. E nessa busca da interpretação correta do social, é preciso não olvidar que a ação intelectual que o cientista faz incidir sobre o seu objeto de estudo é justamente isso, uma construção teórica que pretende traduzir uma verdade que não se tem certeza absoluta de que cumpre tal papel; desta forma, não se deve descartar a sua falibilidade ou probabilidade do falso que pode conter, fato que somente o futuro e os problemas no uso da fórmula proposta podem levantar. Assim, é preciso deixar claro as opções teóricas interpretativas em seus diversos níveis, que foram utilizadas para a construção de uma interpretação do social, estão sempre conforme a ciência do ser humano permite, no estágio atual de seu desenvolvimento.

A construção do sentido de vida e de mundo que se vive, é um processo simbólico de educação que todas as pessoas se inserem inexoravelmente dentro de um espaço social. Aqueles que se omitem, aqueles que agem com certa consciência, 
aqueles que em tudo se envolvem, aqueles que pouco se envolvem, enfim, quem participa e não participa nos eventos cotidiano - em diversas dimensões - para deixar uma marca participativa e valorativa do que fundamentalmente entende ser certo ou errado ser feito, todos estão atuando para marcar indelevelmente a qualidade de relações e de construção de sentido de mundos social em que todos se inserem. Trata-se de um processo subjetivo que esconde muito da verdade acerca da realidade concreta que está sendo construída, mas que está inscrita - esse conjunto de subjetividade - na realidade objetiva que historicamente, paulatinamente vem sendo construída e revelada em toda sua verdade nos constrangimentos e facilidades a que todos estão submetidos para poderem fazer algo que se constitua um avanço qualitativo em sua condição social de vida, especialmente no aspecto sócio-econômico.

Mas é preciso ter em mente algo muito importante, qual seja, quando está a se revelar-e se sustentar - que o ato de percepção do mundo social é um ato necessariamente implicado diretamente com uma ação do agente social para construir esse mundo social, isso não quer dizer imediata e diretamente que se deva aceitar previamente a existência de toda uma construção racional e intelectual de uma teoria do conhecimento, por parte do agente social, nesse comportamento específico. Verifica-se que o que é essencial, e está sempre a operar na prática diutuma em todos os agentes sociais, é algo que se encontra aquém do nível de representação explícita e da cabal expressão verbal, mas que atua concretamente e presentemente em todos os momentos que faz a experiência concreta do mundo social do agente, e no trabalho de construção que ele comporta.

Mais do que uma "consciência de classe" no sentido marxista, parece que o que aproxima os agentes sociais de uma dada região próxima ou vizinha do espaço social é em realidade um "inconsciente de classe", que os fazem agir e se comportar dentro de certos padrões probabilísticos ou assemelhados. O sentido que cada agente possui sobre o lugar de cada um no espaço social, esse sentido da posição ocupada no espaço social, é do próprio domínio prático da estrutura social no seu conjunto, e que envolve todos os agentes, e que, também, somente se descobre na prática, vale dizer, ao ocupar uma posição na estrutura social, e através dessa posição, o agente acaba por verificar o sentido prático da posição ocupada nessa estrutura social, e se conduzir conforme o sentido pratico dessa posição ocupada conforme a probabilidade de um destino.

Deste modo, o espaço social pode ser construído como uma estrutura de probabilidades voltada para unir ou separar indivíduos, uma estrutura de afinidades ou aversão - oposição - entre os diferentes agentes sociais. E nesse processo de objetivação/subjetivação, desconhecimento/reconhecimento, atua sempre presente o desejo humano individual e coletivo de fazer acontecer o mundo social, de acordo com o que apreende pragmaticamente no próprio ato de agir, obtendo resultados e manifestações que somente a experiência, e a posterior racionalização da experiência, podem lhe indicar em todas as suas conseqüências de verdades sociais, mas que, em vida, nem um indivíduo, nem mesmo um grupo de indivíduos, pode apreender ou assimilar completamente, legando para as gerações futuras o patrimônio de energia social que ele acumulou e manipulou durante sua existência. 
O que ele transfere são todas as regras de um jogo social cujas próprias regras estão em jogo pelos diversos protagonistas, conscientes - até certo ponto - e inconscientemente, e participar desse jogo é inevitável, uma vez que pelo só fato de alguém nascer, ele já faz parte do jogo social em curso. Participar desse complexo jogo social de imposições da visão e divisão legítima de mundo social, implica inevitavelmente em ter um sentido de posição e espaço de ação ou decisão dentro do grupo social a qual se insere. Esse sentido prático do mundo é dado pela função do habitus enquanto um conjunto provável de disposições, atitudes, comportamentos, que faz obter as vantagens da sobrevivência mais eficaz para cada pessoa e grupo social em dinâmica luta, através das relações ou inter-relações próximas ou distantes que estabelecem entre si.

Para compreender o habitus, naquilo que ele pode ajudar o cientista social a desvelar verdades sobre o mundo social, e que ajudou a Pierre Bourdieu compreender melhor as determinações que guiam as disposições dos diferentes agentes, inseridos em campos sociais diversos e que aparentemente não se relacionariam entre si, o estudo que ele fez sobre textos de Erwin Panofsky é exemplar para estudo do babitus, enfim, sua presença inscrita nos corpos e mente das pessoas e os efeitos que produz, como um destino inscrito numa probabilidade objetivamente extraida da realidade social em que o agente se encontra emergido. Além disso, esse estudo que Bourdieu fez, e que o levou a considerar seriamente as disposições humanas marcadas pelo babitus, especialmente as suas determinações quanto ao sentido prático de mundo que ele encerra, é também uma lição sobre o proceder - o fazer ciência - na pesquisa social, revelando - frente a uma tradição consagrada do modo de se fazer ciência - o quanto está aberto o campo da pesquisa científica para novas abordagens ou metodologias, reveladoras sobre uma verdade que se encontra à espera para ser revelada, através de uma atitude mais ousada do investigador.

Essas disposições humanas, as inclinações "naturais" a que o ser humano se conduz, e que estão incorporados em forma de habitus em seu corpo, não nascem do nada, elas são construídas culturalmente, dentro de um longo e contínuo processo de inculcação a que aos agentes estão submetidos por viver em sociedade. Tais disposições, revelando probabilidades de condutas, não podem ser consideradas inexoráveis, no sentido de que seriam programações mecânicas que os agentes reproduziriam indefinidamente, uma vez que o ser humano é submetido continuamente a processos de inculcações novos, pelas próprias hutas - disputas sobre o princípio de visão e divisão do mundo social - que ele se envolve e que colocam sempre em questão os princípios de visão e divisão de mundo que tais disposições encerram em si. Para explicar como se dá esse processo de naturalização de pensamentos e comportamentos que marcam as pessoas, talvez o estudo de Pierre Bourdieu, junto com outros autores, acerca da violência simbólica, contribua para refletir melhor as disposições que encerram cada pessoa no mundo social.

A violência simbólica, tratada aqui - arbitrariamente para os fins deste trabalho como princípio de inculcação de um arbitrário cultural, que dá origem aos habitus dos diferentes agentes sociais e grupos de agentes localizados em diferentes posições na estrutura social, é preciso assinalar que como todo processo de violência, está sujeito a um poder que faz aquele realizar-se e cumprir seu destino social. O poder simbólico é correlato à violência simbólica, existindo em todas as lutas socais, em todos os momentos onde um processo pedagógico 
está em curso no mundo social. Para Bourdieu, num dado estado de um campo, onde se vê o poder por toda parte e que torna necessário reconhecê-lo sem dissolvê-lo numa idéia de que ele estaria em toda parte e lugar algum, é necessário saber descobri-lo onde ele se deixa ver menos, onde ele é mais completamente ignorado, portanto, reconbecido: o poder simbólico é, com efeito, esse poder invisível o qual só pode ser exercido com a cumplicidade daqueles que não querem saber que lhe estão sujeitos ou mesmo que o exercem.

A teoria dos campos sociais de Pierre Bourdieu, vem completar esse método epistemológico de construir verdades sobre o funcionamento do mundo social. Assim, aspecto importante a ser destacado, é a aplicação dos saberes acima em diferentes espaços sociais que podem ser constituídos como um campo, a fim de desvelar verdades sociais ali presentes e que necessitam ser ditas para próprio conhecimento dos agentes que atuam nele e, assim, conhecerem melhor o que constitui suas práticas. Desta forma, no estudo do campo jurídico, o conjunto de saberes acima expostos revela o funcionamento de uma realidade social, fundamental para produzir um trabalho de dominação simbólica entre agentes que são ao mesmo tempo concorrentes e cúmplices nesta atividade. $\mathrm{O}$ direito, assim, é forma por excelência do poder simbólico de nomeação que acaba criando as coisas por ele nomeadas onde, ao mesmo tempo e que faz o mundo social, pelo mundo social também ele é feito.

Nesse sentido, constata-se que o sentimento de injustiça ou a capacidade de perceber certa experiência com injusta não é universal, mas depende da posição que a pessoa ocupa no espaço social. O sentimento de injustiça que faz uma pessoa buscar os serviços jurídicos como uma necessidade não é natural, é cultural, é construído, vale dizer, é fruto de um trabalho de construção social que é efetuado pelos profissionais que atuam no campo. O que ocorre é que os profissionais revelam ao mundo social os direitos e estimulam o sentimento de se ter direitos, criando, desta forma, a "descoberta" da sensibilidade e das experiências nominadas como injustas. Nesse sentido eles têm a capacidade de manipular as expectativas de direito, ora criando, ora aumentando ou ora diminuindo a mesma, conforme o caso. Os profissionais da área, assim, acabam produzindo a necessidade de seus próprios serviços, ao traduzirem questões sociais em problemas jurídicos com as probabilidades de êxito conforme cada estratégia possível de ser adotada, e fazem isso guiados pelos seus interesses econômicos, suas atitudes éticas e políticas e seus interesses mais específicos, quais sejam, as suas relações objetivas travadas com os outros especialistas.

Por fim, nessa breve análise, pode-se asseverar que tudo que o ser humano é ou tem sido, coloca-o também como responsável direto e indireto do seu próprio destino, destino esse que é moldado de forma muito especial pelo social. Uma abordagem teórica - e também ações pragmáticas - não pode deixar de considerar a pessoa humana individual e coletiva que nela deve estar inserida, sob pena de desfalcar o elemento fundamental das análises e conclusões - ou resultados -, elemento esse que faz e desfaz o mundo social continuamente, recebendo também todas as injunções que compõe esse mundo. Nada do que se faz neste Planeta está dissociado do indivíduo, e é necessário compreender tudo que esse indivíduo faz para tomar o mundo como ele tem sido. 
A importância da obra de Pierre Bourdieu é que ele justamente realiza a inserção dessa pessoa humana na realidade cotidiana em diversas dimensões sociais como ele pesquisou, e explicar de que forma, inserida numa estrutura social objetiva, essa pessoa, com sua projeção subjetiva da vida e de suas possibilidades práticas frente a ela, contribui para formar a visão do mundo social e mesmo para formar esse mundo, ao mesmo tempo em que é influenciado por esse mundo. Portanto, a sociologia de Bourdieu procura explicar tudo que o social influi no ser humano - sem dissociar o ser humano desse mundo -, tentando muito mais do que invadir espaços científicos e de análises já estabelecidos e/ou consagrados - direto, lingüística, marxismo, filosofia, etnografia etc. -, mas revelar tudo que o social reflete e condiciona determina -, de forma concordante ou discordante - portanto, fazendo avançar o conhecimento científico - frente aos saberes até então consagrados e estabelecidos nessas diversas áreas do conhecimento.

Trata-se de uma complementaridade capital para avançar a ciência social e humana, na busca de verdades cada vez mais corretas ou próximas do que é que constitui como verdade da própria existência humana, particularmente o que o ser humano tem feito e como tem feito. Mas não apenas isso, não há dúvida que a sociologia, com o trabalho de Pierre Bourdieu, ficou mais avançada como ciência rigorosa - mas observando-se a importância que tiveram e ainda têm os autores do passado - e, desta forma, resgatando ou recuperando seus espaços necessários como campo próprio de sua análise, presentes em diversas dimensões das manifestações humanas, naquilo que o coletivo marca e influi determinantemente nas diversas ações e comportamentos praticados pelo indivíduo.

É preciso sempre levar em consideração essa dupla verdade objetiva e subjetiva presente no mundo social e atuante simultaneamente para produzir o que o social revela; e depois da obra de Bourdieu, torna-se cada vez mais difícil recusar essa presença fundamental do indivíduo construindo o que o social - em sua mais ampla dimensão - tem sido. Aquilo que é estrutural e aparentemente determinantes de uma vez por todas, tem sua razão de ser na construção histórica e cultural que a própria sociedade, em suas diversas lutas - ações e omissões - estabeleceu para si, sociedade essa constituída pelos milhares ou milhões de indivíduos - passados e presentes - que concorreram e concorrem, cada qual com sua parte, para produzir e reproduzir o que revela suas história e formação social, vale dizer, um capital sociologicamente pertinente e acumulado, objeto de lutas, e que nessa lutas revela-se o mundo social dali resultante.

Em sociedades solidamente estratificadas - em classes sociais e com um sistema econômico capitalista desenvolvido -, torna-se muito difícil - mas não impossível modificar essa realidade, processo esse que, com toda probabilidade, será lento em sua alteração histórica, como o próprio Bourdieu afirmou numa passagem. Entretanto, o mesmo não se pode afirmar em casos de sociedades pouco estratificadas, uma vez que nelas tudo ainda está por se edificar solidamente e, portanto, parece revelar que a margem de alterações substanciais da realidade se encontra mais aberta, uma vez que as instituições, as estruturas sociais objetivas e as apreensões subjetivas dos indivíduos estão em processo de transição de uma estrutura social para outra. 
Ademais, é forçoso admitir que a ideologia - como visão de mundo de cada um e que produz efeitos concretos ou efetivos no meio social -é melhor explicitada pela teoria que Bourdieu elaborou, para explicar com novo rigor muitas das coisas que sucedem no mundo social, sob o viés do que é que o social influencia para que elas - coisas - sejam assim, no plano mesmo das decisões aparentemente mais individuais em suas escolhas. As inclinações ideológicas, com a teoria de Bourdieu, tornam-se mais reais ou concretas; as diferenças socialmente cultivadas marcam as pessoas e sua posição no espaço social, de tal forma que, dentro de um processo histórico de acumulação de diferentes capitais sociologicamente pertinentes e acumulados, traspassando o mundo social, um agente irá se conduzir conforme todas as probabilidades determinantes que o sentido prático - que condensa toda sua percepção do mundo e sua posição na luta nele desenvolvida - de sua posição lhe determinar.

O que faz a pessoa ver o sentir o mundo como ele vê e sente? Como respostas, têmse os princípios de visão e divisão de mundo, que não só constroem o mundo como ele é, mas refletem a posição de cada um dos seres humanos na sua distribuição dentro de um espaço social, de acordo com um capital - econômico, cultural, social etc. - acumulado e que determinam a visão de cada um nesse mundo, sua posição e dos outros nesse espaço, e as características de determinadas "naturezas" sedimentadas - um algo, uma característica que acompanharia a figura mesma da pessoa - que, desta forma "naturalizada", estão sempre presentes no mundo social estruturalmente, bem como nas apreensões de visão e divisão de mundo que os diferentes agentes contribuem para formar, assim, este mundo, e receberem seus influxos.

A ideologia como falsa representação, até mesmo como um elemento formativo e essencial - intrínseco - da própria personalidade de uma pessoa, ${ }^{80}$ tem, no seu elemento social, um forte componente que explica o por quê das pessoas serem o que são e agirem como agem, fazendo as opções individuais e sociais que fazem. Nascer no mundo é imediatamente receber um capital sociologicamente pertinente como herança, e inserir-se numa luta histórica a qual a pessoa não tem como e não pode furtar-se, pois o simples ato de nascer é já nascer posicionado num ponto de vista desse mundo - a partir da família e sua posição social -, com todas as predisposições prováveis e determinantes que essa localização lhe determina. A partir daí, especialmente seus capitais econômico, cultural e soçial irão ditar sua trajetória social pelos diversos campos sociais, a formação de seu sentido prático no mundo e,

80 ZIZEK, Slavoj. Um mapa da ideologia. Rio de Janeiro: Contraponto, 1996. 338 p. Sobre a temática ideologia, vide também WOLKMER, Antonio Catlos. Ideologia, estado e direito. 3. ed tev. e ampl São Paulo: Revista dos Tribunais, 2000. 230 p.; CHAUI, Marilena. O que é ideologia. 39. ed. São Paulo: Brasiliense, 1996.128 p; KONDER, Leandro. A questão da ideologia. São Paulo. Companhia das Letras, 2002. 280 p; EAGLETON, Terry. Ideologia. São Paulo: Unesp: Boitempo, 1997. 206 p.; LÖWY, Michael Ideologias e ciências social: elementos para uma análise marxista. 14. ed. São Paulo: Cortez, 2000.112 p.; IGLÉSIAS, Ftancisco História e ideologia. 2. ed. São Paulo: Perspectiva, 1981. 304 p; RICOEUR, Paul. Ideologia e utopia. Lisboa: Edições 70, 1991.528 p; HABERMAS, Jürgen. Técnica e ciência como "ideologia”. Lisboa: Edições 70, 1993.150 p.; LYRA FILHO, Roberto. O que é direito. 17. ed. São Paulo: Brasiliense, 2001.96 p.; LÖWY, Michael. As aventuras de Karl Marx contra o Barão de Münchhausen marxismo e positivismo na sociologia do conhecimento. 6. ed. São Paulo: Cortez, 1998. 224 p. 
portanto, reforçando suas disposições - babitus - que, como uma alta probabilidade de se realizar - e outorgar ao agente todos os ganhos materiais e simbólicos sociais esperados -, governarão suas ações e comportamentos individual e social, de acordo com o que a posição social e trajetória social acabam probabilisticamente impondo e se realizando com um destino.

Aí está algo importante saber, vale dizer, o que nós temos sido e porque assim tem sido, pois é o desconhecimento desses mecanismos sociais que tem produzido o mundo historicamente concreto e real, em seus diversos quadrantes, e deste desconhecimento acaba resultando em aceitação natural - doxa - de muitas coisas - especialmente idéias-guias fundamentais - que não têm a correspondência que se deseja dar a elas, a não ser a arbitrariedade de sua origem e sua reprodução, enfim, é desta inconsciência ou desconhecimento do que faz a matéria e substância concreta e real das coisas sociais, é que emerge a força duplicada da legitimação e reconhecimento do próprio mundo como algo que é, tem sido, e será assim mesmo, naturalizando a aceitação, com todas as alegrias e dores aí relacionados, do que é antes de tudo culturalmente e historicamente construído pelas próprias pessoas, de geração em geração, ao longo do tempo. O mundo social é um espaço de negociação, onde por decreto - ou num lance audacioso - nada nele muda, conforme esse decreto deseja realizarse. O sentido prático - babitus, disposições ou predisposições - é forte demais, concreto demais para aceder cegamente a um ato total - isso é contra sua lógica -, pois somente o tempo ditará o resultado das lutas que é possível alcançar, observando-se que o capital sociologicamente pertinente é demorado em sua aquisição, e também em sua perda.

Fundamental também é Bourdieu revelar claramente que cada história e cada cultura enfim, cada povo - engendra seu próprio mundo social, não estando nada revelado de antemão como verdade que govema cada sociedade e o que pode ser realizado nela-especialmente a partir de uma "boa idéia" que, aplicada, produzirá "naturalmente" todas as "boas conseqüências" que dela é "naturalmente" esperada, realizando-se "inevitavelmente" como um destino inescapável , pois se tudo é fruto de uma história e cultural singular, o espaço social é único para cada povo, cada região, cada localidade etc., enfim, o cientista deverá ter a necessidade de revelar e delimitar esse espaços em suas pesquisas, para trazer as verdades que são pertinentes à cada singularidade social estudada, e explicar porque é que fez como pertinentes as escolhas feitas. Cada mundo social é um mundo social particular e deve ser investigado, construído e entendido pertinentemente, a fim de produzir as verdades que ajudem a enxergar e explicar esse mundo, como condição primeira de se pensar rigorosamente os seus problemas e as suas possibilidades. ${ }^{81}$

81. Além das obras já utilizadas e citadas neste trabalho, para compreender melhor o pensamento de Pierre Bourdieu é importante ler as seguintes obras: BOURDIEU, Pierre (Coord.). A miséria do mundo. 2. ed. Petrópolis: Vozes, 1998. 750 p.; BOURDIEU, Pierre; PASSERON, Jean-Claude. Los herederos: los estudiantes y la cultura. Buenos Aires: Siglo XXI, 2003. 190 p.; BOURDIEU, Pierre. El sentido práctico. Madrid: Taurus, 1991. 456 p.; BOURDIEU, Pierre. As regras da arte. São Paulo: Companhia das Letras, 1996. 432 p.; BOURDIEU, Pierre; DARBEL, Alain. O amor pela arte: os museus de arte na Europa e seu público. São Paulo: Edusp: Zouk, 2003. 244 p; BOURDIEU, Pierre. A dominação masculina. Rio de Janeiro: Bertrand Brasil, 1999. 160 p.; BOURDIEU, Pierre. El oficio de científico: ciencia de la ciencia y reflexividad. Barcelona: Anagrama, 2003. 214 p.; BOURDIEU, Pierre. Meditações pascalinas. Rio de Janeiro: Bertrand Brasil, 2001. 322 p; BOURDIEU, Pierre. A ontologia política de Martin Heidegger. Campinas: Papirus, 1989.132 p.; BOURDIEU, Pierre. As estruturas sociais da economia. Lisboa: Piaget, 2001. 288 


\subsection{Possibilidade de aplicação epistemológica do pensamento de Pierre Bourdieu na integração internacional}

Com os saberes acima expostos, parte-se, em seguida, para uma outra parte importante deste trabalho, qual seja, é possível, a partir dos ensinamentos de Pierre Bourdieu, construir uma explicação plausível sobre o que sucede - rumos de avanços e retrocessos - numa integração econômica regional entre Estados específica, no caso, o Mercosul?

Agora, trata-se de verificar a possibilidade de uso epistemológico do pensador francês, desta vez votado para dar continuidade ao deciframento ou interpretação de uma realidade histórico-cultural-social específica, que é acerca da América Latina, vale dizer, a América Espanhola e a América Portuguesa. Um estudo como esse, entende-se que será importante para compreender melhor o que sucede no processo de integração do Cone Sul, uma vez que é pressuposto hipotético o fato de que o Mercosul segue e tem seguido a sorte que é e tem sido traçada histórico-cultural-socialmente entre os povos das duas Américas, mais precisamente, daqueles agentes sociais que mais especificamente estão imbuídos na missão para concretizar uma integração que, se bem sucedida, será um marco histórico fundamental do desenvolvimento ou evolução dessas sociedades e cultura envolvidas, enfim, das próprias civilizações sendo edificadas na América Latina.

Ressalta-se que Pierre Bourdieu, a partir desse momento, é abandonado enquanto produtor de categorias ou conceitos operacionais teóricos que seriam imediatamente aplicados para reproduzir as conclusões mais gerais que seus estudos revelaram - especialmente para o caso europeu -, e, assim, eventualmente ser verificado como se reproduz - e até que ponto - as mesmas verdades européias dentro das sociedades latino-americanas. Diferentemente, Bourdieu é adotado do ponto de vista epistemológico, vale dizer, é um pensamento de ação científica voltado para efetivar um estudo, dentro dos limites objetivos que está circunscrito inexoravelmente um trabalho e a academia brasileira

p.; NOGUEIRA, Maria Alice; CATANI, Afrânio (Orgs.). Pierre Bourdieu/Escritos de educação. Petrópolis: Vozes, 1998. 256 p.; BOURDIEU, Pierre; HAACKE, Hans. Livte-troca: diálogo entre ciência e arte. Rio de Janeiro: Bertrand Brasil, 1995. 136 p.; BOURDIEU, Pierre et alii. Liber 1. São Paulo: Edusp, 1997.324 p; BOURDIEU, Pierre. Intelectuales, política y poder. Buenos Aires: Eudeba, 2003. 272p; BOURDIEU, Pierre. Creencia artística y bienes simbólicos: elementos para uma sociología de la cultura. Córdoba y Buenos Aires: Aurelia Rivera, 2003. 278 p; BOURDIEU, Pierre. Cuestiones de sociología. Madrid: Istmo, 2003. 272 p.; BOURDIEU, Pierre; TEUBENER, Gunther. La fuerza del derecho. Santafé de Bogotá: Siglo del Hombre: Uniandes: Instituto Pensar, 2000. 222 p; BOURDIEU, Pierre. Lições da aula 2. ed. São Paulo: Ática, 1994. 64 p.; BOURDIEU, Pierre. El sociológo y las transformaciones recientes de la economía en la sociedad. Buenos Aires: Universidad de Buenos Aires, 2000.78 p; BOURDIEU, Pierre. Sobre a televisão. Rio de Janeiro: Jorge Zahar, 1997.144 p;; BOURDIEU, Pierre Contrafogos: táticas para enfrentar a invasão neoliberal. Rio de Janeiro: Jorge Zahar, 1998.152 p; BOURDIEU, Pierre. Contrafogos 2: por um movimento social europeu. Rio de Janeiro: Jorge Zahar, 2001.116 p.; BOURDIEU, Pierre. Pensamiento y acción. 2. ed. Buenos Aires: Libros del Zorzal, 2002. 158 p.; LINS, Daniel (org.). A dominação masculina revisitada. Campinas: Papirus, 1998 128 p.; LINS, Daniel (org.). Cultura e subjetividade: saberes nômades. 3. ed Campinas: Papirus, 2002. 120p.; LINS, Daniel (org.). O campo econômico: a dimensão simbólica da dominação/Pierre Bourdieu. Campinas: Papirus, 2000.120 p.; CHARTIER, Roger (org.). Práticas de leitura. 2. ed. rev. São Paulo: Estação Liberdade, 2001. 268 p.; PINTO, Louis. Pierre Bourdieu e a teoria do mundo social. Rio de Janeiro: FGV, 2000. 192 p;; ORTIZ, Renato (org.). A sociologia de Pierre Bourdieu. São Paulo: Olho d'Água, 2003. 172 p; WACQUANT, Loic (org). O mistério do ministério: Pierre Bourdieu e a política democrática. Rio de Janeiro: Revan, 2005.232 p. 
com um todo, a fim de que possa ser levantado o máximo possível de elementos simbólicos determinantes e que estariam a se realizar concretamente no processo de integração internacional em curso. Assim, isso significa que não se buscará enquadrar uma realidade sócio-históricocultural - como a latino-americana - em rijos esquemas teóricos finais ou conclusivos, conforme levantado por Bourdieu em toda sua vida de pesquisador, pois parte-se também do pressuposto - epistemológico - de que nada do que ele escreveu para o caso francês - e outros - é válido, por ilação direta, ao caso específico dos países membros do Mercosul, uma vez que, se verdade sociais há aqui, ele deverão ser extraídos de si próprios - da própria realidade social aqui edificada -, conforme sua formação social e evolução, daí emergindo até onde-estruturalmente - se aproxima do caso francês etc.

Ademais, é preciso ressaltar o seguinte: considerando que, tudo indica, o mundo social - e aqui inserimos o ambiente internacional - é feito pelos indivíduos e grupos de indivíduos, e, desse ambiente, eles recebem o influxo de influências que irão desvelar as verdades objetiva nele presente e as apreensões subjetivas nele em curso, e que, assim, contribuem para a reprodução da objetividade/subjetividade desse espaço social, a pesquisa e análise que será feita - apoiando-se epistemologicamente especialmente em Bourdjeu, mas na mesma medida junto com outros autores que são trabalhados também teoricamente de forma epistemológica - é diferente daquelas elaboradas por Pierre Bourdieu.

De fato, a investigação recairá sobre um espectro mais amplo de ilações simbólicas temporais e espaciais, entretanto, válidos, uma vez que a racionalidade, campo, capital, habitus, ideologia etc. - tudo referido ao contexto específico latinoamericano, portanto, fugindo de um modelo europeu como já consagrado e tradicional, e que seria de antemão medida universal para todos os demais povos - estão presentes diacronicamente e sincronicamente nesse espaço social, produzindo seus efeitos temporais, espaciais e humanos, portanto, determinando - numa medida em que tenta-se desvelar - as injunções ou determinismos que submetem o cotidiano e a evolução dos povos envolvidos na formação do Mercosul.

A reflexão acima remete ao retorno do problema da ciência, vale dizer, o que é legitimo ou não se feito como trabalho científico, na medida em que esse trabalho pode fugir aos padrões tradicionais, portanto consagrados, de se fazer ciência, alcançando verdades que podem contradizer alguns aspectos de entendimentos já estabelecidos, conforme consagrados por uma ou outra corrente científica de análise, no caso, do mundo social. Afinal, é legitimo dogmatizar de uma vez por todas um único tipo e pensamento do que pode ser considerado como a correta conduta científica - e seus resultados -, portanto, de uso de metodologia, de sistema de prova etc.?

Assim, o que Pierre Bourdieu irá influenciar marcantemente, do ponto de vista epistemológico na pesquisa, é em torno fundamentalmente do seguinte:

(I) o mundo social é formado por pessoas e grupos de pessoas, portanto, as instituições podem ser reconduzidas ao que essas gentes fazem;

(II) as significações sociais pertinentes que se dão nesse espaço social são estabelecidas através das relações ou inter-relações concretas que marcam a existência 
das pessoas e grupos de pessoas - o que eles fazem ou deixam de fazer, especialmente porque agem de específica forma -;

(III) as condutas humanas e sociais são marcadas por pré-disposições sociais determinantes - babitus -, cujo conteúdo é histórico-cultural e, portanto, deve ser revelado através de um trabalho científico empírico, conforme condições sociais de dado contexto histórico-social-cultural (um caso dos muitos possíveis, mas real e concreto);

(IV) o conhecimento da história da formação social, com sua trajetória de favorecimentos ou vicissitudes, bem como as suas opções sociais, é importante e reveladora para interpretação de uma dada formação social - de tudo que socialmente esteve em jogo como resultado das relações sociais em disputa -, junto com pesquisas de campo que afiram presentemente, de que forma o passado e o futuro estão negociando no presente, reproduzindo disposições-históricas, ou suplantando em favor de outras novas pré-disposições. ${ }^{82}$

Assim, as relações internacionais e o direito internacional dela decorrente sofrem influxo, vale dizer, são determinadas pelo conjunto de fatores culturais ou civilizatórios que estão inseridos cada povo nesse processo de contato e aproximação que contém toda carga de interesses dos seus protagonistas. Sucede que se os interesses são conjunturais e históricos, eles também são determinados por um longo percurso temporal que, forjados pelo passado, alcançam o presente condicionando as expectativas e ações integrativas passíveis de serem efetuadas em cada época, e preparando as possibilidades futuras de inter-relacionamento recíproco e interdependência de sociedades diferentes no espaço internacional.

Relações internacionais e direito internacional, vistos, assim, como fruto de opções civilizatórias arbitrárias, ${ }^{83}$ se imbricam forçosamente com a filosofia, política, economia, sociologia, antropologia, psicologia e história, por exemplo. Cada povo é uma singularidade formada pelo conjunto civilizatório ou cultural próprio, produto de forças e lutas

82 O ser humano vê, ouve, sente, pensa e fala sobre as coisas que percebe, e, nesse processo, acaba por fixar uma nomeação das coisas, extraindo verdades - compreensões, entendimentos, explicações, traduções, desvelamentos - dessas nomeações e renomeações das coisas por ele nomeadas. Talvez fosse uma questão saber se as vęrdades que extrai, tendo por base os nomes das coisas, não foram, de certa forma, previamente fixadas pelo ato próprio de nomeação - e tudo que nele está racionalmente em jogo, de forma consciente e inconsciente -, colocando sempre em questão por que isso é isso e por que as coisas são o que são, e mesmo o que é a verdade das coisas. No mundo social, a comunicação - em seus diversos meios de manifestação -, bem como os tipos específicos de racionalidades subjacentes a ela, revelam serem as vias fundamentais de interação humana e das significações sociais - construção de mundo. Sobre a importância da comunicação no mundo social, e seus efeitos sistêmicos, vide: MCLUHAN, Marshall. Os meios de comunicação como extensões do homem. 5. ed. São Paulo: Cultrix, 1979.; LUHMANN, Niklas; e DE GEORGI, Raffaele. Teoría de la sociedad. México: Universidad de Guadalajara; Universidad Iberoamericana; Instituto Tecnológico y de Estudios Superiores de Occidente, 1993.; LUHMANN, Niklas. O direito da sociedade (Das Recht der Gesellschaft). Mimeo. Tradução provisória para o espanhol de Javier Torres Nafarrate.; BUCKLEY, Walter. A sociologia e a moderna teoria dos sistemas. 2. ed. São Paulo: Cultrix, 1976. 308 p.; WIENER, Norbert. Cibemética e sociedade: o uso humano dos seres humanos. 5. ed. São Paulo: Cultrix, 1978.192 p.

83 Afrrmar a arbitrariedade de ações e comportamentos humanos é reconhecer que muito das suas opções são escolhas ideológicas - ideologia visto aqui num sentido amplo, como um conjunto de visão de mundo que todas as pessoas são forçosamente ou inevitavelmente dotadas, a fim de existirem posicionadas (com pensamentos e formas práticas de ações, atitudes e respostas) num espaço social com as suas infinitas possibilidades de demandas provenientes do inter-relacionamento entre gentes - e que, portanto, se formam como uma entre diversas outras opções possíveis, mas cujo meio social praticamente acaba impondo e 
internas - e respectivas influências externas - para definição dos legítimos rumos da respectiva sociedade, sendo que o resultado dessas lutas acaba retomando - realimentando - sobre os comportamentos e atitudes das pessoas nas diversas esferas de atuação social, desde a familia até o Estado, passando pelas diferentes instituições privadas e públicas erigidas no corpo social, inclusive as instituições de ordem ético-moral, que permeiam a existência e sobrevivência das gentes.

Diante disso, todas as conseqüências positivas ou negativas, que tais processos integrativos - com seus respectivos arcabouços jurídicos - proporcionam, estão também vinculados a esse conjunto cultural ou civilizacional que marca a integração, favorecendo-a ou desfavorecendo-a, direcionando seus ganhos para o conjunto total da sociedade ou apenas uma parcela reduzida dela, observando que o favorecimento ou desfavorecimento da integração também pode significar a sonegação de maior bem-estar social para uma ampla parcela das populações envolvidas, especialmente as mais humildes e pobres, bastando que os agentes envolvidos no processo não abram mão dos sacrifícios necessários - especialmente das elites - em prol de toda sociedade ou manipulem o processo apenas para favorecer alguns poucos atores sociais em cada sociedade envolvida.

\section{Conclusão}

A sociologia de Pierre Bourdieu conseguiu retraduzir o meio social de forma profícua, explicando, dentro de um viés diferenciado, as práticas de diferentes agentes sociais, referindo-os ao coletivo humano em ação em diferentes esferas de atuação social, mas também ao tempo - história -, ao espaço - cultura e civilização que nele se edifica - e ao habitus - padrões (estatutos) de comportamento que se consagram especialmente de forma inconsciente - que emerge dessa realidade. Mas falar em habitus implica em inter-relacioná-los imediatamente com capital social, campo social, classe social, violência simbólica, entre outros, pois tudo se inter-relaciona ao mesmo tempo para explicar o mundo social.

Fundamentalmente, Bourdieu revelou o ser humano, enfim, a pessoa humana concreta em inter-relação social e qual foi o resultado concreto decorrente desse encontro indivíduosociedade, estabelecendo - sem dissociar - o indivíduo e sua coletividade - portanto, a coletividade e os indivíduos ao mesmo tempo-como agentés reais e concretos produtores de verdades sociais simbólicas que se materializam na realização do cotidiano diuturno vivenciado pelas pessoas, tais como seus ganhos, investimentos, felicidades, dores, perdas, reconhecimentos etc. no campo da inter-relação social.

naturalizando como uma regra moral natural e normal num longo percurso de tempo no seio da convivência. Essa aleatoriedade na escolha de uma opção moral entre tantas - arbitrário --, também pode converter-se numa outra arbitrariedade, ou seja, o uso da força - fisica e/ou psíquica, portanto, simbólica em última instância - para impor e manter a normalidade social. Sobre 0 assunto, especificamente uma atuação da violência simbólica, vide: BOURDIEU, Pierre e PASSERON, Jean Claude. A reprodução: elementos para uma teoria do sistema de ensino. 3 ed. Rio de Janeiro: Francisco Alves, 1992. 
Do ponto de vista epistemológico, essa centralidade no real e concreto produzido simbolicamente por essas pessoas em ação individual-coletiva é ponto de partida para se pensar uma integração econômica regional, uma vez que, no fundo, não são meras instituições que a promovem - em realidade as instituições envolvidas são também produtos históricos de gentes em coexistência social marcando culturalmente sua existência -, mas pessoas que simbolicamente estão marcadas e que produzem e reproduzem arbitrários culturais que resultam, dentre outros, nos avanços e retrocessos que se podem medir dentro do processo de integração.

Um habitus não é um conceito fechado, cuja significação está produzida de uma vez por todas; cada país, civilização, sociedade, cultura, conforme desenvolvimento civilizacional, histórico, cultural, produzirá o conjunto de habitus que a marcarão contextualmente ou historicamente. $\odot$ problema, então, é verificar a possibilidade de identificar no estudo da sociedade esse conjunto unívoco de escolhas de pessoas, de bens, de práticas, que tornaram possível um tipo específico de sociedade - um caso do possível - dentre tantas que o ser humano coletivamente construiu.

Se tudo que o ser humano é ou tem sido coloca-o também como responsável direto e indireto do seu próprio destino, destino esse que é moldado de forma muito especial pelo social, então, como já asseverado, o Mercosul segue e tem seguido a sorte que é e tem sido traçada histórico-cultural-socialmente entre os povos das duas Américas, mais precisamente, daqueles agentes sociais que mais especificamente estão imbuídos na missão para concretizar uma integração. E para isso é preciso decifrar ou interpretar, no caso concreto do Mercosul, uma realidade histórico-cultural-social específica, que é a América Latina, vale dizer, a América Espanhola e a América Portuguesa, a partir das ações, omissões e práticas de suas gentes, em especial, suas elites. 